\title{
Green Synthesis of Selenium and Tellurium Nanoparticles: Current Trends, Biological Properties and Biomedical Applications
}

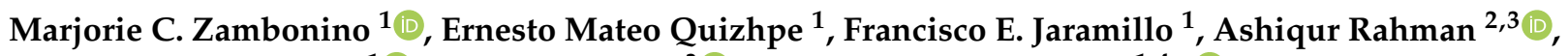 \\ Nelson Santiago Vispo ${ }^{1}\left(\mathbb{D}\right.$, Clayton Jeffryes $^{3}$ (D) and Si Amar Dahoumane ${ }^{1,4, *(D)}$ \\ 1 School of Biological Sciences and Engineering, Yachay Tech University, Hacienda San José s/n, \\ San Miguel de Urcuquí 100119, Ecuador; marjorie.zambonino@yachaytech.edu.ec (M.C.Z.); \\ ernesto.quizhpe@yachaytech.edu.ec (E.M.Q.); francisco.jaramillo@yachaytech.edu.ec (F.E.J.); \\ nvispo@yachaytech.edu.ec (N.S.V.) \\ 2 Center for Midstream Management and Science, Lamar University, Beaumont, TX 77710, USA; \\ arahman2@lamar.edu \\ 3 Center for Advances in Water and Air Quality \& The Dan F. Smith Department of Chemical Engineering, \\ Lamar University, Beaumont, TX 77710, USA; cjeffryes@lamar.edu \\ 4 Department of Chemical Engineering, Polytechnique Montréal, C.P. 6079, Succ. Centre-ville, \\ Montréal, QC H3C 3A7, Canada \\ * Correspondence: sa.dahoumane@gmail.com or si-amar.dahoumane@polymtl.ca
}

Citation: Zambonino, M.C.; Quizhpe, E.M.; Jaramillo, F.E.; Rahman, A.; Santiago Vispo, N.; Jeffryes, C.; Dahoumane, S.A. Green Synthesis of Selenium and Tellurium Nanoparticles: Current Trends, Biological Properties and Biomedical Applications. Int. J. Mol. Sci. 2021, 22, 989. https://doi.org/10.3390/ ijms22030989

Received: 28 December 2020

Accepted: 18 January 2021

Published: 20 January 2021

Publisher's Note: MDPI stays neutral with regard to jurisdictional claims in published maps and institutional affiliations.

Copyright: (c) 2021 by the authors. Licensee MDPI, Basel, Switzerland. This article is an open access article distributed under the terms and conditions of the Creative Commons Attribution (CC BY) license (https:/ / creativecommons.org/licenses/by/ $4.0 /)$.

\begin{abstract}
The synthesis and assembly of nanoparticles using green technology has been an excellent option in nanotechnology because they are easy to implement, cost-efficient, eco-friendly, risk-free, and amenable to scaling up. They also do not require sophisticated equipment nor well-trained professionals. Bionanotechnology involves various biological systems as suitable nanofactories, including biomolecules, bacteria, fungi, yeasts, and plants. Biologically inspired nanomaterial fabrication approaches have shown great potential to interconnect microbial or plant extract biotechnology and nanotechnology. The present article extensively reviews the eco-friendly production of metalloid nanoparticles, namely made of selenium (SeNPs) and tellurium (TeNPs), using various microorganisms, such as bacteria and fungi, and plants' extracts. It also discusses the methodologies followed by materials scientists and highlights the impact of the experimental sets on the outcomes and shed light on the underlying mechanisms. Moreover, it features the unique properties displayed by these biogenic nanoparticles for a large range of emerging applications in medicine, agriculture, bioengineering, and bioremediation.
\end{abstract}

Keywords: SeNPs; TeNPs; nanofactories; biosynthesis; biomass; mechanistic aspects; bioactivity; bioapplications; sustainability

\section{Introduction}

Nanotechnology has become one of the most promising interdisciplinary technologies, connecting physics, chemistry, biology, materials science, electronics, and medicine [1]. The quantity of engineered nanoparticles (NPs) is expected to increase significantly in the years to come as they receive growing global attention due to their attractive properties, multifunctionalities, unique characteristics, and innovative applications in different industrial and scientific domains [2-6]. Several physical and chemical methods have been extensively explored to fabricate NPs, such as laser ablation $[7,8]$, coprecipitation $[9,10]$, hydrothermal route [11,12], solvothermal route [13,14], sol-gel process [15,16], polyol process $[17,18]$, electrochemical methods $[19,20]$, sonochemistry $[21,22]$, and microwaveassisted methods $[23,24]$. However, the use of toxic chemicals and/or the generation of harmful byproducts limit their application in clinical fields. Thus, materials scientists rely on a plethora of precursors and reducing/stabilizing agents from biological resources 
to produce environmentally friendly NPs to lower or eliminate the use and generation of hazardous chemicals [25-27]. Such biosystems include natural biomolecules [28-31], plants [32-34], algae [35-40], bacteria [41,42], yeast and fungi [43,44]; these biological entities exhibit high reductive capacities due to the presence of enzymes, proteins, lipids, sugars, and metabolites. Overall, the biological-mediated synthesis of metallic and metalloid nanoparticles is a single-step, bioreductive process that follows a bottom-up approach and involves the reduction of metal ions dissolved usually in aqueous solutions at room or mild temperature and atmospheric pressure $[33,45,46]$.

Nanoparticles have remarkable advantages over bulk materials, such as a larger surface area, higher surface energy, spatial confinement and reduced imperfections [47]. Their features, such as the size, morphology, chemical composition, surface functionality, and crystallinity, play an important role in determining their potential applications in numerous fields, such as biomedicine, nanobiotechnology, agriculture, pharmacology, optoelectronics, etc. [48-50]. Over the past few years, selenium and tellurium have become chalcogenides of great interest owing to their unique photoconductive and thermoconductive properties [51]. They are known as "E-tech" elements with characteristics similar to that of sulfur and are fundamental constituents of photovoltaic solar panels, electronic devices, and alloys [51,52].

Selenium is an essential trace element for life [53,54]. It is an allotropic nonmetal usually red and grey present in nature under three forms: amorphous, crystalline trigonal with helical chains, and crystalline monoclinic $(\alpha, \beta, \gamma)$ with Se8 rings [6]. The synthesis of selenium nanoparticles (SeNPs) by microorganisms and plants induces variations in their crystallinity, morphology, and size due to the diversity of the followed biological methodologies, reducing enzymes and biosurfactants [55]. Although some investigations have reported the biosynthesis of SeNPs under aerobic and anaerobic conditions, aerobic microorganisms have generated the ideal outcomes [56]. The process typically reduces selenite (Se(IV)) or selenate (Se(VI)) species into elemental selenium (Se(0)). Se-based nanomaterials exhibit chemotherapeutic and chemopreventive features, antioxidant properties, low cytotoxicity, and anticancer efficacy, making them a useful tool in nanomedicine $[57,58]$. They also have a strong, dose-dependent antimicrobial effect on various microorganisms' growth and propagation [56].

Tellurium is a metalloid present in nature as a soluble oxyanion under four oxidation states: $-2\left(\mathrm{H}_{2} \mathrm{Te}\right),+2\left(\mathrm{TeO}_{2}{ }^{2-}\right),+4\left(\mathrm{TeO}_{3}{ }^{2-}\right)$, and $+6\left(\mathrm{TeO}_{4}{ }^{2-}\right)$. It can be toxic in very low concentrations $\left(1 \mu \mathrm{g} \mathrm{mL}^{-1}\right)$ [59]. Recently, the conversion of tellurite to black elemental tellurium including extra/intracellular accumulation, volatilization, and methylation, has piqued the interest of researchers [60]. Tellurium nanoparticles (TeNPs) have become of interest in research and industry due to their excellent biocompatibility [61], antimicrobial, antioxidant and anticancer activity [62,63], and their ability to reduce cholesterol and triglyceride levels [64]. The high efficiency of microorganisms to transform metalloid oxyanions to less toxic elemental forms results in toxicity reduction and increased selenium and tellurium bioavailability [65]. Moreover, the same microorganisms provide exceptional bioremediation tools and technological applications due to their ability to biorecover the cations of these metalloids and promote the subsequent production of Se and $\mathrm{Te}$ nanomaterials [51,66-70]. The principal applications of biogenic SeNPs and TeNPs are summarized in Figure 1. 


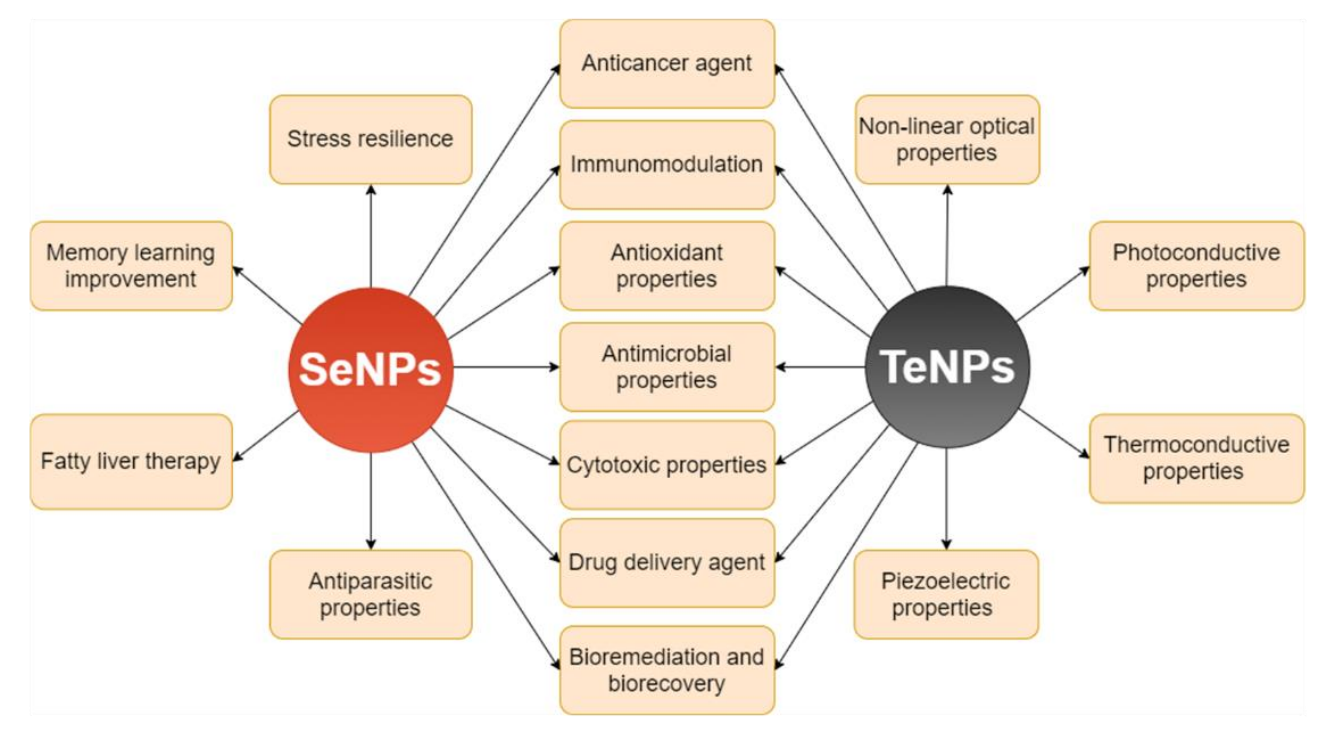

Figure 1. Applications of selenium nanoparticles (SeNPs) and tellurium nanoparticles (TeNPs).

The present review aims at providing a comprehensive insight upon the emerging routes implemented for the biosynthesis of SeNPs and TeNPs using various microorganisms and plants via different methodologies. It also elaborates on the underlying mechanisms that govern these bioprocesses, describes the unique biological properties of these metalloids' nanomaterials, and discusses their diverse applications in the biomedical field.

\section{Green Synthesis of Inorganic Nanoparticles Using Microorganisms}

The holy grail in nanotechnology consists in elaborating cost-effective and environmentally friendly approaches for the synthesis of nanomaterials that modulate their size, morphology, assembly, and colloidal stability [71]. The biosynthesis of inorganic nanoparticles is generally implemented in aqueous media at room temperature or mild heating and atmospheric pressure [26]. Those are simple conditions that engage the production of high-quality nanomaterials. In that sense, these NP biosynthetic methods that rely on microorganisms, such as bacteria, fungi, microalgae, yeast and viruses, and plants are fully eco-friendly approaches [42]. These microbial and plant-assisted methodologies provide easy, inexpensive, and nontoxic routes to yield NPs that exhibit a diversity of sizes, shapes, and composition along with unique physicochemical attributes and outstanding biological properties.

Nature has devised several reliable, cost-effective, nontoxic, clean, and ecofriendly biological techniques to produce SeNPs and TeNPs [72,73]. Green nanotechnology employs natural biological resources, such as bacteria, fungi, yeast, algae, plants, and viruses, and, most often, water as the solvent. To achieve the fabrication of monodispersed, highly stable NPs with a desired size and controlled morphology, the biomolecular machinery availability is needed [74]. The main benefit is that microorganisms are effective tools that act as nanofactories avoiding thus the use of and/or generation of harsh, toxic chemicals. They also have the ability to accumulate and detoxify heavy metals due to various reductase enzymes that reduce metal salts to metallic nanoparticles with a narrow size distribution and, therefore, less polydispersity $[75,76]$. Biological processes usually occur at mild conditions, i.e., ambient temperature and atmospheric pressure, and do not require skilled professionals nor sophisticated equipment making them amenable to controlled and scaleup procedures [74]. However, they also present some limitations related to NP composition, crystallinity, morphology, and size distribution.

Recently, the extra- and intra-cellular microbial production of metallic/metalloid NPs have been studied [27,33,41,43-45,77-79]. In extracellular formation, the added metal salts are transformed into NPs in the culture broth or attached to the cell membrane. Conversely, the intracellular process first transports the metal ions through the cell membrane, i.e., in- 
ternalization, to the cell interior where the nanoparticles are formed. Then, these internally formed NPs are released to the supernatant using several procedures, such as the cell lysis, to be recovered and purified $[72,74,80]$. The following sections describe the outstanding role played by different microorganisms, namely bacteria, fungi and yeast, and plants in the biosynthesis of SeNPs and TeNPs.

\section{Parameters Affecting the Green Synthesis of Metalloid Nanoparticles}

Various factors, such as the precursor, biomass type, temperature, $\mathrm{pH}$, and reaction time, govern the production and stabilization of SeNPs and TeNPs by microorganisms. The $\mathrm{pH}$ is an important factor that determines the shape, size, and composition of the NPs $[80,81]$. For instance, Wu et al. reported the formation, at $\mathrm{pH} 8$, of effectively dispersed spherical SeNPs of $60 \mathrm{~nm}$ in diameter in epigallocatechin-3-gallate (EGCG). However, the protonation of the EGCG in acidic conditions ( $\mathrm{pH}$ 1.0) rapidly induced the aggregations of these NPs as their dimensions reached $300 \mathrm{~nm}$ within the first 3 min resulting eventually in the loss of their nanoscale features [82]. According to Akçay and Avc1, the maximum yield occurred at $\mathrm{pH} 7$ and 8 [83] while Kuroda et al. reported the optimum reduction rate at $\mathrm{pH}$ values of 6-9 for selenite and 7-9 for selenate [84]. Wadhwani et al. demonstrated the synthesis of SeNPs in a $\mathrm{pH}$ range of 4-10 [58]. No synthesis occurred at $\mathrm{pH} 2$ and $1.5 \mathrm{mM}$ of sodium selenite due to the presence of less functional groups that are required for the reduction process. The precursor concentration can also control the NP shape and size. For example, the same study by Wadhwani et al. proved that spherical and rod morphologies of the SeNPs appear at $3.0 \mathrm{mM} \mathrm{Na}_{2} \mathrm{SeO}_{3}$ while only spheres are observed at $1.5 \mathrm{mM}$ of the same precursor [58].

Green approaches for the synthesis of SeNPs and TeNPs are cost- and energy-efficient, requiring lower temperatures compared to their chemical or physical counterparts [58]. The temperature is found to be a factor that leads to the formation and then aggregation of SeNPs [85]. For instance, the reduction process occurs at temperatures up to $40{ }^{\circ} \mathrm{C}$ using Acinetobacter sp. SW30 and higher temperatures (around $80^{\circ} \mathrm{C}$ and $100{ }^{\circ} \mathrm{C}$ ) may lead to the aggregation of the SeNPs into nanorods [58]. It is relevant to indicate that, in the case of bacteria, elevated temperatures $\left(>45^{\circ} \mathrm{C}\right)$ may block the normal biosynthesis of SeNPs [86]. Likewise, high temperatures (over $60^{\circ} \mathrm{C}$ ) and low temperatures (below $25^{\circ} \mathrm{C}$ ) reduce the efficiency of inorganic NP production using fungi $[87,88]$. Moreover, the incubation time plays a significant role in the quality and morphology of the NPs. In the case of most bacteria, the average incubation time ranges from 24 to $72 \mathrm{~h}$, but long incubation periods may cause NPs to aggregate, grow, or shrink [89]. The properties of NPs may have a lifetime, but extended exposure times can induce metastable changes to the surface morphology, crystallinity, and optical absorption of nanostructures [90].

The concentration of precursors and reducing/surfactant agents are also critical to control the growth and morphology of the nanoparticles [26,91-93]. The precursor concentration can have a strong influence on the color intensity and rate of change during the $\mathrm{NP}$ formation process [94,95]. Se $\left(\mathrm{Na}_{2} \mathrm{SeO}_{4}, \mathrm{Na}_{2} \mathrm{SeO}_{3}, \mathrm{SeO}_{2}\right)$ and $\mathrm{Te}\left(\mathrm{Na}_{2} \mathrm{TeO}_{3}, \mathrm{~K}_{2} \mathrm{TeO}_{3}\right)$ precursors along with the $\mathrm{pH}$ and reaction time are tuned to produce metalloid nanostructures of different sizes $[49,96]$ and shapes (e.g., SeNPs, Te nanorods (TeNRs), Te nanowires (TeNWs), and Te nanotubes (TeNTs)) [97,98]. Additionally, the size of SeNPs is determined by the initial precursor concentration [99]. The tolerance towards selenium oxyanions can be evaluated by exposing the microorganisms to different precursor concentrations. For example, Presentato et al. evaluated the bioconversion yield and rate of 0.5 and $2 \mathrm{mM}$ of $\mathrm{SeO}_{3}{ }^{2-}$ into thermodynamically stable $\mathrm{Se}(0)$ nanostructures considering unconditioned and conditioned physiological states of the actinomycete Rhodococcus aetherivorans BCP1 [99]. The results showed that the initial precursor concentration had a strong effect on the size and size evolution of the obtained SeNPs. For instance, the smallest Se NPs that are obtained at the lowest concentration evolve to form Se nanorods (SeNRs). On the other hand, the longest SeNPs obtained at the highest concentration eventually form the shortest SeNRs. The strain Phomopsis viticola has the same degree of inhibition, in terms of 
biomass production, when incubated in the presence of $\mathrm{SeO}_{3}{ }^{2-}$ or $\mathrm{TeO}_{3}{ }^{2-}[100]$ whereas two strains of Aspergillus, A. flavus DSMZ 1959 and A. parasiticus DSMZ 1300, were less inhibited by $\mathrm{SeO}_{3}{ }^{2}$ compared to $\mathrm{TeO}_{3}{ }^{2-}$ [100]. However, Wang et al. found that different sodium selenite concentrations did not affect the size and morphology of the produced SeNPs using Bacillus subtilis [101].

To optimize SeNP bioproduction, the selenium precursor concentration (sodium selenite) varied from 10 to $30 \mathrm{mM}$ and the impact of the $\mathrm{pH}$ and reaction time was assessed [102]. Besides, statistical optimization techniques might be used for the design of the experiment, such as the response surface methodology (RSM) [102,103]. Overall, the yield of NP synthesis has a direct correlation with the precursor concentration: the higher the concentration, the greater the production. Moreover, it can be suggested that the lower the precursor concentration and temperature, the smaller the size of produced NPs (vide infra).

\section{Techniques of Characterization}

The characterization of metalloid NPs is needed to correlate their physicochemical properties to their biological effects and toxicity [49,104-107]. The initial physicochemical characterization of these NPs is carried out by using a myriad of routine lab techniques to analyze their shape, size and size distribution, porosity, surface chemistry, crystallinity, and dispersion pattern [108]. The most widely used techniques include UV-visible (UV-Vis) spectroscopy, luminescence spectroscopy (LS), scanning electron microscopy-energy dispersive X-ray spectroscopy (SEM-EDX), transmission electron microscopy (TEM), Fourier transform infra-red spectroscopy (FT-IR), X-ray diffraction (XRD). XRD confirms the presence of NPs and determines their lattice structure, crystallinity, and crystallite size using the Debye-Scherrer equation [21]. Electron microscopy techniques, such as TEM and SEM, enable the study of NP shape and size to deduce their size distribution along with elemental composition (EDX) [21,109]. According to Kapur et al., magnified field emission scanning electron microscopy (FESEM) images provide information about the nature and composition of the NPs [108]. The FTIR is an efficient technique that provides reproducible analyses used to reveal the presence of functional groups at the NP surface. These groups may be involved in the reduction of the metal ions and/or the NP capping that ensures the colloidal stability $[58,95]$. In addition to determining the surface charge (z-potential) of the NPs, the dynamic light scattering (DLS) provides the NP hydrodynamic diameter and good insight into their stability/aggregation by measuring their Brownian motion [108]. The atomic force microscopy (AFM) provides quantitative information about length, width, height, morphology, and surface texture of NPs through a tridimensional visualization [56].

\section{Microbial Biosynthesis of Selenium Nanoparticles}

\subsection{Using Bacteria}

In recent years, the biosynthesis of Se-containing NPs using bacteria has been reported as a new environmentally friendly route that offers tremendous advantages, such as easy handling, short synthesis times, and simple genetic manipulation [101]. Various bacteria reduce inorganic selenite $\left(\mathrm{SeO}_{3}{ }^{2-}\right)$ or selenate $\left(\mathrm{SeO}_{4}{ }^{2-}\right)$ to elemental red selenium $\mathrm{Se}(0)$ nanoparticles of various morphologies including spherical, hexagonal, polygonal, and triangular ones [109]. The academic community has extensively explored the aerobic and anaerobic bacteria involved in the production of SeNPs (Table 1) through various reduction pathways under both aerobic and anaerobic conditions [56,73,110-113]. However, further investigations are required to fully determine the underlying biochemical pathways and the biochemicals that govern these processes. 
Table 1. Biosynthesis of SeNPs using bacteria.

\begin{tabular}{|c|c|c|c|c|c|c|c|c|c|c|}
\hline Species & Localization & Precursor & $\begin{array}{l}\text { Concentration } \\
(\mathrm{mM})\end{array}$ & $\begin{array}{c}\text { Incubation } \\
\text { Temperature and } \\
\text { Time }\end{array}$ & Size $(\mathrm{nm}) *$ & $\begin{array}{l}\text { Color and } \\
\text { Shape }\end{array}$ & $\begin{array}{l}\text { Z-Potential } \\
\quad(\mathrm{mV})\end{array}$ & $\begin{array}{c}\text { Sample } \\
\text { Quantification }\end{array}$ & Activity/Application & Ref. \\
\hline $\begin{array}{l}\text { Staphylococcus } \\
\text { carnosus }\end{array}$ & Intracellular & $\mathrm{Na}_{2} \mathrm{SeO}_{3}$ & $1-5$ & $37^{\circ} \mathrm{C}$ for $72 \mathrm{~h}$ & $439-525$ & $\begin{array}{c}\text { Red } \\
\text { Spherical }\end{array}$ & $\begin{array}{c}-26.13 \text { and } \\
-20.40\end{array}$ & $\begin{array}{l}\text { Cocktail of } \\
\text { proteins derived } \\
\text { from S. carnosus }\end{array}$ & $\begin{array}{l}\text { Agriculture } \\
\text { Future medicine }\end{array}$ & [109] \\
\hline $\begin{array}{l}\text { Bacillus mycoides } \\
\text { Stenotrophomonas } \\
\text { maltophilia }\end{array}$ & $\begin{array}{l}\text { Cell free } \\
\text { extract }\end{array}$ & $\mathrm{Na}_{2} \mathrm{SeO}_{3}$ & 2 & $27^{\circ} \mathrm{C}$ for $6 \mathrm{~h}$ or $24 \mathrm{~h}$ & $160-171$ & Spherical & -70 and -80 & $\begin{array}{l}\text { C: } 73-75 \% \\
\text { O: } 10-11 \% \\
\text { Se: } 9-11 \% \\
\text { P: } 3-5 \% \\
\text { S: } 1 \%\end{array}$ & $\begin{array}{l}\text { Antibacterial } \\
\text { Antibiofilm }\end{array}$ & [114] \\
\hline $\begin{array}{l}\text { Acinetobacter } \\
\text { schindleri } \\
\text { Staphylococcus sci- } \\
\text { uriExiguobacterium } \\
\text { acetylicum } \\
\text { Enterobacter cloacae }\end{array}$ & $\begin{array}{l}\text { Near the cell } \\
\text { membrane }\end{array}$ & $\mathrm{Na}_{2} \mathrm{SeO}_{3}$ & $10-50$ & 25 or $37^{\circ} \mathrm{C}$ for $24 \mathrm{~h}$ & $\sim 100$ & $\begin{array}{c}\text { Spherical } \\
\text { Transformation } \\
\text { to nanowires }\end{array}$ & N/A & Se: $83.9 \%$ & Antibacterial & [115] \\
\hline $\begin{array}{l}\text { Stenotrophomonas } \\
\text { bentonitica }\end{array}$ & $\begin{array}{l}\text { Intracellular } \\
\text { Extracellular }\end{array}$ & $\mathrm{Na}_{2} \mathrm{SeO}_{3}$ & 2 & $28^{\circ} \mathrm{C}$ for $48 \mathrm{~h}$ & $30-400(\sim 34)$ & $\begin{array}{l}\text { Orange-red } \\
\text { Spherical } \\
\text { Hexagonal } \\
\text { Polygonal } \\
\text { Nanowires }\end{array}$ & N/A & $\begin{array}{c}\text { Extracellular } \\
\text { flagella-like } \\
\text { proteins }\end{array}$ & $\begin{array}{c}\text { Bioremediation, } \\
\text { Safety of deep } \\
\text { geological repository } \\
\text { systems }\end{array}$ & [74] \\
\hline Shewanella sp. & $\mathrm{N} / \mathrm{A}$ & $\mathrm{Na}_{2} \mathrm{SeO}_{3}$ & $0.01-1.0$ & $30^{\circ} \mathrm{C}$ for $24 \mathrm{~h}$ & $1-20$ & Spherical & N/A & N/A & N/A & [116] \\
\hline Bacillus sp. & $\begin{array}{l}\text { Intracellular. } \\
\text { Associated to } \\
\text { cell debris }\end{array}$ & $\mathrm{SeO}_{2}$ & 1.26 & $30^{\circ} \mathrm{C}$ for $24 \mathrm{~h}$ & $80-220$ & $\begin{array}{c}\text { Red } \\
\text { Spherical }\end{array}$ & -16.3 & Se: $100 \%$ & $\begin{array}{c}\text { Anticancer } \\
\text { Antibiofilm } \\
\text { Antiparasitic } \\
\text { Antioxidant }\end{array}$ & [117-120] \\
\hline Azoarcus sp. & $\begin{array}{c}\text { Extracellular } \\
\text { Associated to } \\
\text { cell debris }\end{array}$ & $\mathrm{Na}_{2} \mathrm{SeO}_{3}$ & $1-8$ & $30^{\circ} \mathrm{C}$ for $24 \mathrm{~h}$ & 123 & $\begin{array}{l}\text { Orange } \\
\text { Spherical }\end{array}$ & N/A & $\mathrm{N} / \mathrm{A}$ & $\begin{array}{l}\text { Agriculture } \\
\text { Bioremediation }\end{array}$ & [121] \\
\hline Acinetobacter sp. & Intracellular & $\mathrm{Na}_{2} \mathrm{SeO}_{3}$ & $0.1-4$ & $30{ }^{\circ} \mathrm{C}$ for $24 \mathrm{~h}$ & $\sim 100$ & $\begin{array}{c}\text { Red } \\
\text { Spherical } \\
\text { Rod shaped } \\
\text { polygonal }\end{array}$ & +10 & $\begin{array}{l}\text { Proteins } \\
\text { Amines } \\
\text { Amides }\end{array}$ & Anticancer & [58] \\
\hline $\begin{array}{l}\text { Duganella sp. } \\
\text { Agrobacterium sp. }\end{array}$ & $\begin{array}{l}\text { Cell surface } \\
\text { Extracellular } \\
\text { polymeric } \\
\text { substances } \\
\text { (EPS)Culture } \\
\text { medium }\end{array}$ & $\begin{array}{l}\mathrm{Na}_{2} \mathrm{SeO}_{3} \\
\mathrm{Na}_{2} \mathrm{SeO}_{4}\end{array}$ & $\begin{array}{l}4 \mathrm{~g} \mathrm{~L}^{-1} \\
2 \mathrm{~g} \mathrm{~L}^{-1}\end{array}$ & $28 \pm 2{ }^{\circ} \mathrm{C}$ & $100-220$ & $\begin{array}{c}\text { Red } \\
\text { Spherical }\end{array}$ & N/A & Proteins & Agriculture & [110] \\
\hline
\end{tabular}


Table 1. Cont.

\begin{tabular}{|c|c|c|c|c|c|c|c|c|c|c|}
\hline Species & Localization & Precursor & $\begin{array}{l}\text { Concentration } \\
(\mathrm{mM})\end{array}$ & $\begin{array}{c}\text { Incubation } \\
\text { Temperature and } \\
\text { Time }\end{array}$ & Size $(\mathrm{nm}) *$ & $\begin{array}{l}\text { Color and } \\
\text { Shape }\end{array}$ & $\begin{array}{l}\text { Z-Potential } \\
\quad(\mathrm{mV})\end{array}$ & $\begin{array}{c}\text { Sample } \\
\text { Quantification }\end{array}$ & Activity/Application & Ref. \\
\hline $\begin{array}{l}\text { Burkholderia } \\
\text { fungorum }\end{array}$ & $\begin{array}{c}\text { Mostly } \\
\text { extracellular }\end{array}$ & $\mathrm{Na}_{2} \mathrm{SeO}_{3}$ & $0.5-2$ & $27^{\circ} \mathrm{C}$ for $96 \mathrm{~h}$ & $170-200$ & $\begin{array}{l}\text { Red-orange } \\
\text { Spherical }\end{array}$ & From -25 to +20 & Proteins & Bioremediation & [122] \\
\hline $\begin{array}{l}\text { Comamonas } \\
\text { testosteroni }\end{array}$ & $\begin{array}{c}\text { Intracellular: } \\
\text { cytoplasm or } \\
\text { periplasm }\end{array}$ & $\begin{array}{l}\text { Se(IV) and } \\
\text { Se(VI) }\end{array}$ & 5 & $28^{\circ} \mathrm{C}$ for $48 \mathrm{~h}$ & $100-200$ & Red fine-grained & N/A & $\begin{array}{c}\text { Selenium } \\
\text { content } 100 \%\end{array}$ & Bioremediation & [123] \\
\hline Bacillus subtilis & Extracellular & Selenite & 4 & $48^{\circ} \mathrm{C}$ for $48 \mathrm{~h}$ & $50-400$ & $\begin{array}{c}\text { Red } \\
\text { Spherical } \\
\text { monoclinic that } \\
\text { can transform to } \\
\text { anisotropic 1D } \\
\text { trigonal } \\
\text { structure } \\
\text { (nanowires) }\end{array}$ & $\mathrm{N} / \mathrm{A}$ & $\begin{array}{l}\text { Proteins } \\
\text { Biopolymers }\end{array}$ & Biosensing & [101] \\
\hline Alishewanella sp. & Intracellular & $\mathrm{Na}_{2} \mathrm{SeO}_{3}$ & 1 & $37^{\circ} \mathrm{C}$ for $4 \mathrm{~h}$ & $100-220$ & Spherical & -28.7 & $\begin{array}{l}\text { Proteins } \\
\text { Lipids } \\
\text { Organic } \\
\text { substances } \\
\text { Inorganic ions }\end{array}$ & Bioremediation & [75] \\
\hline $\begin{array}{l}\text { Azospirillum } \\
\text { brasilense }\end{array}$ & Extracellular & $\begin{array}{l}\mathrm{Na}_{2} \mathrm{SeO}_{3} \\
\mathrm{Na}_{2} \mathrm{SeO}_{4}\end{array}$ & $1-5$ & $30^{\circ} \mathrm{C}$ & 400 & $\begin{array}{c}\text { Red } \\
\text { Spherical }\end{array}$ & -18 & $\begin{array}{c}\text { Proteins } \\
\text { Carbohydrates } \\
\text { EPS }\end{array}$ & $\begin{array}{l}\text { Bioremediation } \\
\text { Biotechnological } \\
\text { applications }\end{array}$ & [125] \\
\hline $\begin{array}{l}\text { Pseudomonas } \\
\text { aeruginosa }\end{array}$ & Cell surface & Selenite & $0.25-1.0$ & $37^{\circ} \mathrm{C}$ for $24-72 \mathrm{~h}$ & $47-165(\sim 96)$ & $\begin{array}{c}\text { Red } \\
\text { Spherical }\end{array}$ & 251.8 & Proteins & Bioremediation & [126] \\
\hline $\begin{array}{l}\text { Stenotrophomonas } \\
\text { maltophilia }\end{array}$ & $\begin{array}{l}\text { Intracellular } \\
\text { Released to } \\
\text { the medium }\end{array}$ & $\mathrm{Na}_{2} \mathrm{SeO}_{3}$ & $0.5-5.0$ & $27^{\circ} \mathrm{C}$ for 24 and $48 \mathrm{~h}$ & $160-250$ & Spherical & 140 & $\begin{array}{c}\text { Proteins } \\
\text { Carbohydrates } \\
\text { Lipids }\end{array}$ & Bioremediation & [113] \\
\hline Bacillus cereus & Intracellular & $\mathrm{Na}_{2} \mathrm{SeO}_{3}$ & $0.5-1200$ & $30^{\circ} \mathrm{C}$ for $24 \mathrm{~h}$ & 170 & $\begin{array}{c}\text { Red } \\
\text { Spherical }\end{array}$ & N/A & N/A & $\begin{array}{c}\text { Medicine } \\
\text { Veterinary medicine }\end{array}$ & [127] \\
\hline Zooglea ramigera & Extracellular & $\mathrm{Na}_{2} \mathrm{SeO}_{3}$ & 3 & $30^{\circ} \mathrm{C}$ for $48 \mathrm{~h}$ & $30-150$ & $\begin{array}{c}\text { Red } \\
\text { Spherical } \\
\text { Nanorods } \\
\text { (trigonal) }\end{array}$ & $\mathrm{N} / \mathrm{A}$ & $\begin{array}{l}\text { Enzymes } \\
\text { Proteins } \\
\text { Bacterial } \\
\text { material }\end{array}$ & N/A & [128] \\
\hline
\end{tabular}


Table 1. Cont.

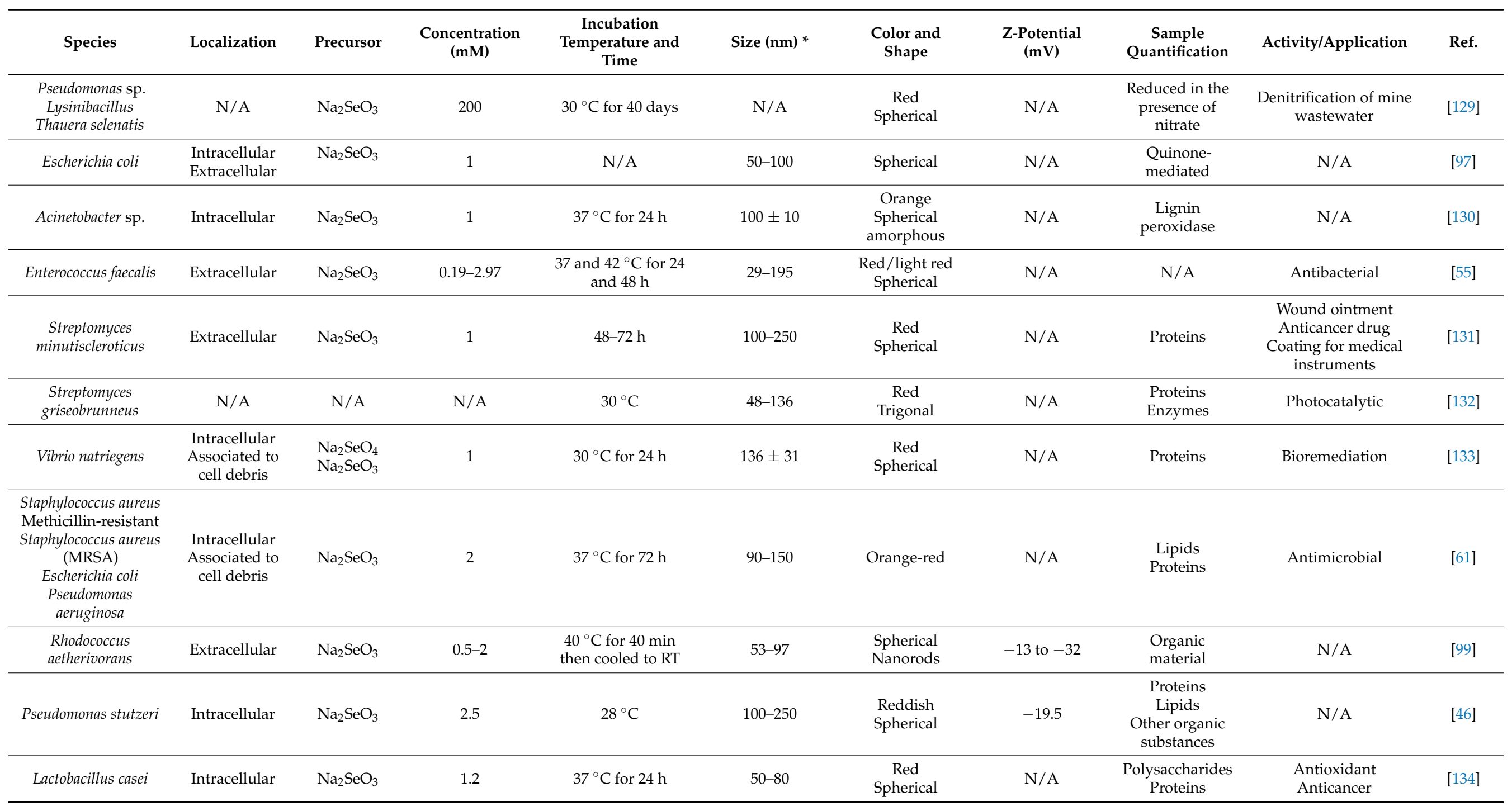


Table 1. Cont.

\begin{tabular}{|c|c|c|c|c|c|c|c|c|c|c|}
\hline Species & Localization & Precursor & $\begin{array}{c}\text { Concentration } \\
(\mathrm{mM})\end{array}$ & $\begin{array}{c}\text { Incubation } \\
\text { Temperature and } \\
\text { Time }\end{array}$ & Size $(\mathrm{nm})$ * & $\begin{array}{l}\text { Color and } \\
\text { Shape }\end{array}$ & $\begin{array}{l}\text { Z-Potential } \\
\quad(\mathrm{mV})\end{array}$ & $\begin{array}{c}\text { Sample } \\
\text { Quantification }\end{array}$ & Activity/Application & Ref. \\
\hline $\begin{array}{l}\text { Streptomyces } \\
\text { enissocaesilis }\end{array}$ & Extracellular & $\mathrm{SeO}_{2}$ & 5 & $30^{\circ} \mathrm{C}$ for $72 \mathrm{~h}$ & $20-211$ & $\begin{array}{l}\text { Brown, orange } \\
\text { and deep yellow } \\
\text { Spherical }\end{array}$ & -220 & Proteins & Antimicrobial & [135] \\
\hline Pseudomonas stutzeri & N/A & $\mathrm{Na}_{2} \mathrm{SeO}_{3}$ & $1-3$ & $37^{\circ} \mathrm{C}$ for $48 \mathrm{~h}$ & $75-200$ & $\begin{array}{l}\text { Bright red } \\
\text { Spherical }\end{array}$ & -46.2 & $\begin{array}{l}\text { Proteins } \\
\text { Organic } \\
\text { molecules }\end{array}$ & $\begin{array}{l}\text { Antiangiogenic } \\
\text { Antiproliferative }\end{array}$ & [103] \\
\hline Streptomyces sp. & Extracellular & $\mathrm{Na}_{2} \mathrm{SeO}_{3}$ & 1 & $28^{\circ} \mathrm{C}$ for $72-96 \mathrm{~h}$ & $20-150$ & $\begin{array}{c}\text { Red } \\
\text { Spherical }\end{array}$ & N/A & $\begin{array}{l}\text { Free amines } \\
\text { Aromatic rings } \\
\text { Cysteine } \\
\text { residues } \\
\text { Amides }\end{array}$ & $\begin{array}{l}\text { Antibacterial } \\
\text { Larvicidal } \\
\text { Anthelminthic }\end{array}$ & [136] \\
\hline Lysinibacillus sp. & Extracellular & $\mathrm{Na}_{2} \mathrm{SeO}_{3}$ & 1 & $37^{\circ} \mathrm{C}$ for 3 days & 130 & $\begin{array}{c}\text { Red } \\
\text { Spherical }\end{array}$ & -19.1 to -28.8 & $\begin{array}{c}\text { Proteins } \\
\text { Polysaccharides } \\
\text { Fatty acids }\end{array}$ & $\begin{array}{l}\text { Antibiofilm } \\
\text { Antimicrobial }\end{array}$ & [137] \\
\hline $\begin{array}{l}\text { Lactobacillus } \\
\text { acidophilus } \\
\text { L. plantarum } \\
\text { L. rhamnosus }\end{array}$ & Extracellular & $\mathrm{Na}_{2} \mathrm{SeO}_{3}$ & 4 & $35^{\circ}$ for $48 \mathrm{~h}$ & $20-80$ & Red & N/A & Proteins & $\mathrm{N} / \mathrm{A}$ & [76] \\
\hline Idiomarina sp. & Intracellular & $\mathrm{Na}_{2} \mathrm{SeO}_{3}$ & 4 and 8 & $37^{\circ} \mathrm{C}$ for $48 \mathrm{~h}$ & 35 and $150-350$ & $\begin{array}{c}\text { Brick red } \\
\text { Spherical/Hexagonal }\end{array}$ & $\mathrm{N} / \mathrm{A}$ & $\mathrm{N} / \mathrm{A}$ & $\begin{array}{c}\text { Antineoplastic } \\
\text { Anticancer }\end{array}$ & [138] \\
\hline Ralstonia eutropha & Extracellular & $\mathrm{Na}_{2} \mathrm{SeO}_{4}$ & 1.5 & $30^{\circ} \mathrm{C}$ for $48 \mathrm{~h}$ & $40-120$ & $\begin{array}{c}\text { Red } \\
\text { Spherical/Nanorods } \\
\end{array}$ & -7.7 & $\mathrm{~N} / \mathrm{A}$ & Antibacterial & [139] \\
\hline Pseudomonas stutzeri & $\begin{array}{l}\text { Extracellular } \\
\text { Cell surface }\end{array}$ & $\begin{array}{l}\mathrm{Na}_{2} \mathrm{SeO}_{4} \\
\mathrm{Na}_{2} \mathrm{SeO}_{3} \\
\end{array}$ & $\begin{array}{c}5 \text { and } 11 \mathrm{mM} \\
4 \text { and } 9 \mathrm{mM}\end{array}$ & $34^{\circ} \mathrm{C}$ for 7 days & $\leq 200$ & $\begin{array}{c}\text { Red } \\
\text { Spherical }\end{array}$ & $\mathrm{N} / \mathrm{A}$ & $\mathrm{N} / \mathrm{A}$ & Bioremediation & [84] \\
\hline Enterobacter cloacae & $\begin{array}{l}\text { Intracellular } \\
\text { Extracellular }\end{array}$ & $\mathrm{Na}_{2} \mathrm{SeO}_{3}$ & $0.5-15$ & $37^{\circ} \mathrm{C}$ for $8 \mathrm{~h}$ & $100-300$ & $\begin{array}{c}\text { Red } \\
\text { Rod-shaped }\end{array}$ & $\mathrm{N} / \mathrm{A}$ & $\begin{array}{l}\text { Organic } \\
\text { material }\end{array}$ & $\mathrm{N} / \mathrm{A}$ & [140] \\
\hline Bacillus cereus & $\begin{array}{l}\text { Intracellular } \\
\text { Extracellular }\end{array}$ & $\mathrm{Na}_{2} \mathrm{SeO}_{3}$ & $0.5-10$ & $37^{\circ} \mathrm{C}$ for $48 \mathrm{~h}$ & $150-200$ & Spherical & -46.86 & Proteins & N/A & [56] \\
\hline $\begin{array}{l}\text { Stenotrophomonas } \\
\text { maltophilia } \\
\text { Ochrobactrum sp. }\end{array}$ & $\mathrm{N} / \mathrm{A}$ & $\mathrm{Na}_{2} \mathrm{SeO}_{3}$ & 0.5 & $27^{\circ} \mathrm{C}$ for 24 and $48 \mathrm{~h}$ & 357 & Spherical & $\mathrm{N} / \mathrm{A}$ & $\begin{array}{l}\text { Organic } \\
\text { compounds }\end{array}$ & $\begin{array}{l}\text { Antimicrobial } \\
\text { Antibiofilm }\end{array}$ & [71] \\
\hline Shewanella oneidensis & $\begin{array}{l}\text { Cell surface } \\
\text { Extracellular }\end{array}$ & Selenite & 0.5 & $30^{\circ} \mathrm{C}$ for $6-48 \mathrm{~h}$ & 20 & $\begin{array}{c}\text { Red } \\
\text { Spherical }\end{array}$ & N/A & EPS & $\mathrm{N} / \mathrm{A}$ & [141] \\
\hline
\end{tabular}


Table 1. Cont.

\begin{tabular}{|c|c|c|c|c|c|c|c|c|c|c|}
\hline Species & Localization & Precursor & $\begin{array}{l}\text { Concentration } \\
(\mathrm{mM})\end{array}$ & $\begin{array}{c}\text { Incubation } \\
\text { Temperature and } \\
\text { Time }\end{array}$ & Size $(\mathrm{nm}) *$ & $\begin{array}{l}\text { Color and } \\
\text { Shape }\end{array}$ & $\begin{array}{l}\text { Z-Potential } \\
\text { (mV) }\end{array}$ & $\begin{array}{c}\text { Sample } \\
\text { Quantification }\end{array}$ & Activity/Application & Ref. \\
\hline $\begin{array}{c}\text { Synechococcus } \\
\text { leopoliensis }\end{array}$ & $\begin{array}{l}\text { Intracellular } \\
\text { Extracellular }\end{array}$ & $\mathrm{Na}_{2} \mathrm{SeO}_{3}$ & 5 & $35^{\circ} \mathrm{C}$ & $\begin{array}{l}254 \pm 52 \\
200 \pm 37\end{array}$ & $\begin{array}{l}\text { Red-brown } \\
\text { Fused spheres } \\
\text { Elongated rods }\end{array}$ & N/A & $\mathrm{N} / \mathrm{A}$ & N/A & [142] \\
\hline $\begin{array}{l}\text { Comamonas } \\
\text { testosteroni }\end{array}$ & Extracellular & $\mathrm{Na}_{2} \mathrm{SeO}_{3}$ & $0.2-50$ & $28^{\circ} \mathrm{C}$ for $24 \mathrm{~h}$ & 100-200 & $\begin{array}{c}\text { Red } \\
\text { Round } \\
\text { Rod-shaped }\end{array}$ & $\mathrm{N} / \mathrm{A}$ & Proteins & Bioremediation & [143] \\
\hline $\begin{array}{l}\text { Azospirillum } \\
\text { brasilense }\end{array}$ & Extracellular & $\mathrm{Na}_{2} \mathrm{SeO}_{3}$ & $10-50$ & $31-32{ }^{\circ} \mathrm{C}$ for $24 \mathrm{~h}$ & $25-80$ & $\begin{array}{l}\text { Red-orange } \\
\text { Spherical }\end{array}$ & -21 to -24 & $\mathrm{~N} / \mathrm{A}$ & N/A & [144] \\
\hline Bacillus cereus & Cell surface & $\mathrm{Na}_{2} \mathrm{SeO}_{3}$ & $0.25-1.0$ & $37^{\circ} \mathrm{C}$ for $24-72 \mathrm{~h}$ & 50-150 ( 93) & $\begin{array}{c}\text { Red } \\
\text { Rod-shaped }\end{array}$ & $-31.1 \pm 4.9$ & $\mathrm{~N} / \mathrm{A}$ & Bioremediation & [145] \\
\hline Bacillus sp. & Extracellular & $\mathrm{SeO}_{2}$ & 6.4 & $33^{\circ} \mathrm{C}$ for $72 \mathrm{~h}$ & $31-335$ ( 126) & $\begin{array}{l}\text { Red-orange } \\
\text { Spherical }\end{array}$ & $\mathrm{N} / \mathrm{A}$ & $\begin{array}{c}\text { Alcohols } \\
\text { Phenols } \\
\text { Amides } \\
\text { Amines } \\
\text { Amino acids }\end{array}$ & Antioxidant & [83] \\
\hline
\end{tabular}

* An inorganic particle is considered as a nanomaterial if one of its dimensions ranges between 1 and $100 \mathrm{~nm}$. 
The following species have been screened under aerobic conditions: Streptomyces minutiscleroticus M10A62 [131], Comamonas testosteroni S44 [143], Lactobacillus sp., Bifidobacterium sp. and Streptococcus thermophilus [146], Enterobacter cloacae Z0206 [140], Azospirillum brasilense [125] and the gram + bacteria Bacillus strains: Bacillus sp. MSh-1 [117,147], B. subtilis [101], and B. cereus [127]. On the other hand, several species of anaerobic bacteria have been screened for their ability to promote the production of SeNPs, such as Shewanella sp. HN-41 [116], S. oneidensis MR-1 [141], Stenotrophomonas bentonitica [71], Alishewanella sp. WH16-1 [75], Vibrio natriegens [133], and the facultative anaerobic bacteria L. casei 393 [134,148]. Moreover, anaerobic upflow sludge blanket reactors are used to fabricate SeNPs [53,149-151]. Besides, some species are able to biosynthesize SeNPs under aerobic and/or anaerobic conditions, such as Azoarcus sp. CIB [121].

The aerobic Se-reducing bacteria are simpler, faster, and more effective synthesizers of SeNPs as they grow rapidly and produce more cells [123]. They also possess greater advantages in agriculture and bioremediation over anaerobic bacteria since the soil and water treatment occurs aerobically [152-154]. Other benefits lie in their ability to identify the functional microbiota and the molecular homeostatic mechanisms responsible for Se oxyanion reduction. For example, in the case of the aerobic strain C. testosteroni $S 44$, which can resist the toxicity of some heavy metal cations, such as $\mathrm{Cu}^{2+}, \mathrm{Zn}^{2+}, \mathrm{As}^{4+}$, and $\mathrm{Se}^{4+}$, the reduction of $\mathrm{Se}(\mathrm{VI})$ to SeNPs is carried out by the sulfite reductase (CysIJ) enzyme in the sulfate assimilation pathway [123]. This pathway has been suggested to be the general mechanism of selenate $(\mathrm{Se}(\mathrm{VI}))$ reduction in aerobic organisms related to the selenium biocycle. Moreover, the $\mathrm{Cr}(\mathrm{VI})$ reductase (known as $\mathrm{CsrF}$ ) in the genome of Alishewanella sp. WH16-1 has been reported as a novel bacterial aerobic selenite reductase [75]. Due to its similarities with the structure and reduction activity of the flavoenzymes $\mathrm{ChR}$, FerB and ArsH, CsrF may also act as a Se(IV) reductase.

In anaerobic bacteria, $\mathrm{Se}(\mathrm{VI}) / \mathrm{Se}(\mathrm{IV})$ reduction can occur on the cell surface via a two-step process; first, $\mathrm{Se}(\mathrm{VI})$ is reduced to Se(IV), then Se(IV) is reduced to subsequently give rise to SeNPs [155]. Conversely, in aerobic bacteria, it is more challenging to reduce Seoxyanions on the surface of cells due to the tendency of oxygen to accept the electrons prior to Se(IV) $[123,156]$. Therefore, the reduction occurs intracellularly and then Se(0)/SeNPs are exported extracellularly by cell lysis [53,157], rapid expulsion pathway [158], efflux via a vesicular secretion system [155], vesicular transport [159], and hyphal lysis or fragmentation [160]. Nevertheless, the specific efflux system is still unknown.

Estevam et al. produced SeNPs using Staphylococcus carnosus TM300 that were harvested by first sonicating the pellet and then separating the NPs by ulterior centrifugations [109]. Cocktails of proteins were attached to the SeNP surface to act as potential natural stabilizers that prevent the formation of precipitates at the flask's bottom. Moreover, these SeNPs exhibited nematicidal activity against the nonpathogenic nematode Steinernema feltiae and biological activity against E. coli and S. cerevisiae, for bacterial and yeast infections, respectively. Wadhwani et al. detailed the SeNP synthesis by challenging the cell suspension and total cell proteins (TCP) of Acinetobacter sp. SW30 with sodium selenate [58]. This cell suspension formed spherical SeNPs of $78 \mathrm{~nm}$ in diameter after $6 \mathrm{~h}$ incubation and transformed into rod-like structures after $48 \mathrm{~h}$. These selenium structures were observed at different $\mathrm{pH}$ values ranging from 6 to 10 and two precursor concentrations (1.5 and $3.0 \mathrm{mM}$ ) (Figure 2). On the other hand, polygonal-shaped SeNPs of $79 \mathrm{~nm}$ in size were obtained in the supernatant at $4 \mathrm{mg} \mathrm{mL}^{-1}$ of TCP. 


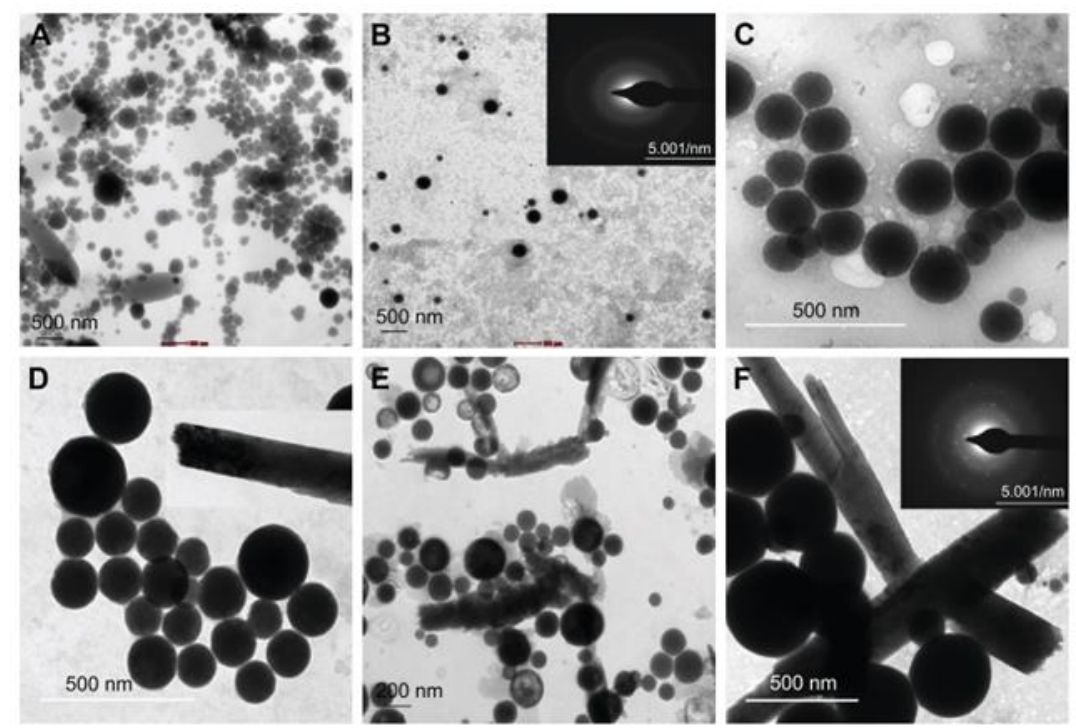

Figure 2. Transmission Electron Microscopy images of biogenic SeNPs synthesized by incubating the cell suspension of Acinetobacter sp. at $37^{\circ} \mathrm{C}$ with $1.5 \mathrm{mM} \mathrm{Na}_{2} \mathrm{SeO}_{3}$ at: (A) pH 6, (B) pH 7 and (C) $\mathrm{pH}$ 9. TEM micrographs of the same experiment when the $\mathrm{Na}_{2} \mathrm{SeO}_{3}$ concentration is brought to $3.0 \mathrm{mM}$ at (D) $\mathrm{pH}$ 6, (E) $\mathrm{pH} 7$, and (F) $\mathrm{pH} 9$. Reproduced from [58] with permission from Dove Medical Press.

Moreover, Fernández-Llamosas et al. reported that the anaerobic beta-proteobacteria Azoarcus sp. CIB is tolerant to selenite oxyanions and acts as a good biocatalyst synthesizing electron-dense SeNPs in its stationary growth phase [121]. This study proposed the existence of an energy-dependent selenite exporter to minimize the intracellular accumulation of the as-produced SeNPs by transporting them out of the cell. Tugarova et al. suggested a general mechanism of SeNP biosynthesis by Aspergillus brasilense [144]. The process involves the transport of Se ions to the cell interior where they are reduced into elemental $\mathrm{Se}(0)$ nuclei; these nuclei are then released to the supernatant where the extracellular biosynthesis of SeNPs occurs. The synergistic inhibition effect of these SeNPs in combination with six antibiotics was tested against pathogenic bacteria. Furthermore, the rhizobacterium $A$. brasilense appears to biotransform selenite to mixed selenium-sulfur NPs with a sulfate concentration of $800 \mathrm{mg} \mathrm{L}^{-1}$; this mechanism is suitable for bioremediation, agriculture, nanobiotechnology, and medical applications [125].

Figueroa et al. reported the in vivo and in vitro synthesis of Se and Te nanostructures using Acinetobacter schindleri and Staphylococcus sciuri from a total of 47 bacterial strains [115]. Triangular, spherical, and rod-like Se nanostructures were also efficiently fabricated in vitro using E. cloacae glutathione reductase (GorA) in both crude extracts and purified protein. Similar studies investigated biomolecules involved in mediating the reduction of selenium oxyanions to elemental selenium or SeNPs, such as glutathione (GSH) [140,156,161], glutathione reductase [162], proteins [75,163], thioredoxin reductase [162,164], SerABC reductase [165], fumarate reductase [140,141], NADH-dependent enzymes [166], NADH flavin oxidoreductase [84,166], membrane-bound SrdBCA amino acid sequence [167], DMSO reductase family of molybdoproteins [168], sulfite reductase [169], hydrogenase I [170], nitrite reductase [171], chromate selenite reductase flavoenzyme (CsrF) [75], and other enzymes and biosurfactants [172,173].

In addition, some biomolecules have been found to act as reducing, capping, and/or stabilizing agents and play a fundamental role in altering the features of SeNPs and controlling their size distribution [56,145]. For instance, Ruiz Fresneda et al. indicated that extracellular flagella-like proteins can biotransform the amorphous $\mathrm{Se}(0)$ nanospheres to crystalline and polycrystalline one dimensional (1D) trigonal Se(0) nanostructures with distinct shapes, such as nanowires and polygons [74]. Moreover, Wang et al. used Bacillus subtilis to obtain semiconducting spherical monoclinic SeNPs that could be transformed 
into 1-D trigonal nanowires with an actinomorphic nature [101]. This process might involve an oriented attachment mechanism based on the Ostwald ripening mechanism. Moreover, proteins present in the solution are thought to provide long-term stability to the SeNPs and prevent their agglomeration. Another study using Burkholderia fungorum strain DBT1 determined aerobic selenite reduction can be attributed to cytoplasmic enzymatic activation mediated by electron donors [122]. The same study suggested that an organic layer surrounding the SeNPs, composed of extracellular matrix (ECM) that includes carbohydrates, proteins, and humic-like substances, stabilizes the particles by modifying their zeta potential.

Previous studies also highlighted the importance of the protein fraction released by microorganisms to externally coat nanoparticles to increase electrostatic repulsions and, consequently, increase their colloidal stability [174-176]. This characteristic is essential to maintain the long-term stability, avoid the aggregation and prevent the transformation of colloidal SeNPs into the black amorphous Se form [56]. This is evidenced in high negative z-potential values that are indicative of particle repulsion. For example, carbonyl groups of amino acid residues [142] and SH groups of L-cysteine [177] can strongly bind to metal NPs and form a biomolecular, stabilizing, and protecting cap.

\subsection{Using Fungi}

The mycogenic biosynthesis of inorganic NPs has been extensively investigated due to the advantages of fungi over bacteria and actinomycetes $[178,179]$. Fungi are easy to culture and manipulate, and can grow in highly concentrated media with heavy metal cations. They can also survive and reproduce in high selenium concentrations. The main advantages of NP mycosynthesis are easy scaling-up, low-cost downstream processing and easy manipulation, low-cost and viability of the fungal biomass [180]. Furthermore, fungi release reductive proteins and enzymes into the extracellular medium; these biomolecules reduce Se ions into harmless, precipitating SeNPs [181]. The general process of microbially assisted synthesis of SeNPs and TeNPs is shown in Figure 3.

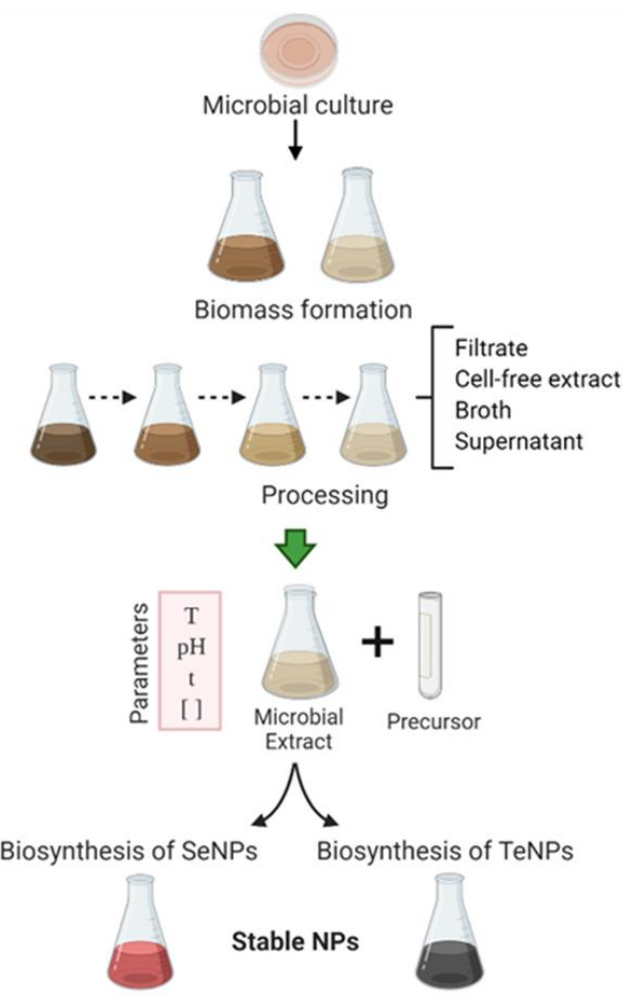

Figure 3. Schematic diagram detailing the microbially assisted procedure of metalloid nanoparticles. 
Numerous fungal species reduce selenite/selenate to intra- or extracellular SeNPs (Table 2). Under extracellular conditions, Diko et al. reported the synthesis of spherical and pseudospherical SeNPs using the supernatant of Trichoderma sp. WL-Go in culture broth [182]. Liang et al. used four fungal species: Aureobasidium pullulans, Mortierella humilis, Trichoderma harzianum, and Phoma glomerata, to produce SeNPs and TeNPs and provide nucleation sites with extracellular protein and polymeric substances [183]. Mosallam et al. combined $\gamma$-rays and the supernatant of $A$. oryzae to produce SeNPs and found a strong correlation between the antioxidant capacity and both the phenolic content and SeNP yield [184]. Moreover, the biomimetic mycosynthesis of SeNPs with simple preparation protocols from, for instance, Alternaria alternata yields uniform and stable SeNPs [180].

Table 2. Biosynthesis of SeNPs by fungi.

\begin{tabular}{|c|c|c|c|c|c|}
\hline Species & Location & Size (nm) & Shape & Activity/Application & Ref. \\
\hline Trichoderma sp. & Extracellular & $20-220$ & $\begin{array}{c}\text { Spherical } \\
\text { Pseudospherical }\end{array}$ & $\mathrm{N} / \mathrm{A}$ & [182] \\
\hline Pleurotus ostreatus & Aqueous extract & $7-28$ & Spherical & $\begin{array}{l}\text { Antioxidant } \\
\text { Antimicrobial } \\
\text { Anticancer }\end{array}$ & [185] \\
\hline $\begin{array}{l}\text { Penicillium } \\
\text { chrysogenum }\end{array}$ & $\begin{array}{c}\text { Cell-free } \\
\text { supernatant }\end{array}$ & $48-50$ & Spherical & $\begin{array}{l}\text { Antimicrobial } \\
\text { Antibiofilm }\end{array}$ & [186] \\
\hline $\begin{array}{l}\text { Phanerochaete } \\
\text { chrysosporium }\end{array}$ & $\begin{array}{l}\text { Intracellular } \\
\text { Extracellular }\end{array}$ & $50-600$ & Spherical & Bioremediation & [65] \\
\hline Polyporus umbellatus & $\mathrm{N} / \mathrm{A}$ & $\begin{array}{c}212 \pm 23 \\
82 \pm 1\end{array}$ & Spherical & $\begin{array}{c}\text { Anticancer } \\
\text { Antiproliferative }\end{array}$ & [187] \\
\hline $\begin{array}{c}\text { Auricularia } \\
\text { auricula-judae }\end{array}$ & $\begin{array}{l}\text { Embedded in } \\
\text { triple helix } \\
\beta-(1,3)-D \text {-glucan }\end{array}$ & 60 & Hollow nanotubes & $\begin{array}{c}\text { Acute myeloid } \\
\text { leukemia (AML) } \\
\text { therapy }\end{array}$ & [188] \\
\hline Trichoderma atroviride & $\begin{array}{c}\text { Culture filtrate } \\
(\mathrm{CF}) \\
\text { Cell lysate }(\mathrm{CL}) \\
\text { Cell wall debris } \\
(\mathrm{CW})\end{array}$ & $60-123$ & Spherical & $\begin{array}{c}\text { Production of crop } \\
\text { plants (tomatoes) } \\
\text { Management of plant } \\
\text { diseases }\end{array}$ & [181] \\
\hline $\begin{array}{c}\text { Aureobasidium } \\
\text { pullulans } \\
\text { Mortierella humilis } \\
\text { Trichoderma harzianum } \\
\text { Phoma glomerata }\end{array}$ & Extracellular & $48-78$ & Spindle-shaped & Bioremediation & {$[51]$} \\
\hline Dictyophora indusiata & Intracellular & 89 & Spherical & Anticancer & [189] \\
\hline $\begin{array}{l}\text { Catathelasma } \\
\text { ventricosum }\end{array}$ & $\mathrm{N} / \mathrm{A}$ & 50 & Spherical & Antidiabetic & [190] \\
\hline Aspergillus oryzae & $\mathrm{N} / \mathrm{A}$ & 55 & Spherical & Antimicrobial & [184] \\
\hline $\begin{array}{c}\text { Pyrenochaeta sp. } \\
\text { Acremonium strictum } \\
\text { Plectosphaerella } \\
\text { cucumerina } \\
\text { Stagonospora sp. } \\
\text { Alternaria alternata } \\
\text { Paraconiothyrium } \\
\text { sporulosum }\end{array}$ & $\begin{array}{l}\text { Fungal hyphae } \\
\text { Intracellular } \\
\text { Extracellular }\end{array}$ & $50-300$ & Spherical & $\mathrm{N} / \mathrm{A}$ & [191] \\
\hline Alternaria alternata & Extracellular & $30-150$ & Spherical & $\mathrm{N} / \mathrm{A}$ & [180] \\
\hline
\end{tabular}


Table 2. Cont.

\begin{tabular}{|c|c|c|c|c|c|}
\hline Species & Location & Size (nm) & Shape & Activity/Application & Ref. \\
\hline $\begin{array}{l}\text { Pleurotus ostreatus } \\
\text { Lentinus edodes } \\
\text { Ganoderma lucidum } \\
\text { Grifola frondosa }\end{array}$ & $\begin{array}{l}\text { Intracellular } \\
\text { Extracellular }\end{array}$ & 50-150 & Spherical & $\mathrm{N} / \mathrm{A}$ & [192] \\
\hline Lentinula edodes & $\begin{array}{c}\text { Intracellular } \\
\text { (fungal hyphae) }\end{array}$ & $180 \pm 17$ & $\mathrm{~N} / \mathrm{A}$ & $\mathrm{N} / \mathrm{A}$ & [193] \\
\hline $\begin{array}{l}\text { Pleurotus ostreatus } \\
\text { Ganoderma lucidum } \\
\text { Grifola frondosa }\end{array}$ & $\begin{array}{l}\text { Intracellular } \\
\text { Cell-free filtrate }\end{array}$ & $20-550$ & $\mathrm{~N} / \mathrm{A}$ & $\mathrm{N} / \mathrm{A}$ & [194] \\
\hline Cordyceps sinensis & $\mathrm{N} / \mathrm{A}$ & $80-125$ & Spherical & Antioxidant & [195] \\
\hline Mariannaea sp. & $\begin{array}{l}\text { Intracellular } \\
\text { Extracellular }\end{array}$ & $\begin{array}{c}45 \\
213\end{array}$ & Spherical & $\mathrm{N} / \mathrm{A}$ & [196] \\
\hline Gliocladium roseum & Cell-free filtrate & $20-80$ & Spherical & $\mathrm{N} / \mathrm{A}$ & [197] \\
\hline
\end{tabular}

The medicinal basidiomycete Lentinus edodes F-249 can transform selenium within organic and inorganic compounds into spherical SeNPs of $\sim 180 \mathrm{~nm}$ [193]. Dictyophora indusiata is a saprophytic fungus able to form a hybrid Se nanostructure by exploiting its novel polysaccharide (DP1) [189]. The DP1-functionalized SeNPs proved to have an antiproliferative effect against HepG2 cancer cells via death receptor- and mitochondria-mediated apoptotic mechanisms.

Some studies have also depicted both the intracellular and extracellular synthesis of SeNPs using fungi $[191,196]$. For example, three fractions of the fungus Trichoderma atroviride, namely the culture filtrate (CF), cell lysate (CL), and cell wall debris (CW), produced bioactive SeNPs that were able to form aggregate fungal spores, thus avoiding the adhesion of the pathogen Phytophthora infestans to the host cell and blocking its infection of tomato plants [181]. A similar mechanism has been reported for Lentinula edodes [193], Mariannaea sp. [196], Fusarium sp., and T. reesei [198]. Other researchers exploited intraand extracellular extracts of the xylotrophic basidiomycetes Pleurotus ostreatus, L. edodes, Ganoderma lucidum, and Grifola frondosa to produce SeNPs of various sizes and shapes [192]. Along with basidiomycetes, other fungal groups, such as Ascomycota and Zygomycota, can also produce nanoparticles, but these mushrooms are known to be allergenic and/or pathogenic to animals and plants [199-201]. Therefore, nontoxic, edible, and cultivated basidiomycetes are a better alternative for biotechnological applications including nanotechnology as the NP synthesis can occur in their mycelia and culture media [192]. Under both extra- and intracellular conditions, the toxicity effects and the removal mechanisms vary according to the fungal species and Se precursors. Rosenfeld et al. demonstrated that six fungal species (P. sporulosum, A. strictum, A. alternata, P. cucumerina, Pyrenochaeta sp., and Stagonospora sp.) constitute an excellent detoxification biosystem that tolerates high Se concentrations and reduces selenite/selenate to Se(0) [191].

El-Sayyad et al. fabricated SeNPs by employing two different eco-friendly green synthetic methodologies: either using Penicillium chrysogenum filtrate or combining P. chrysogenum filtrate with gentamicin drug $(\mathrm{CN})$ as the stabilizing agent after application of $\gamma$-irradiation [186]. The second process resulted in the highest synthesis yield and enhanced antipathogenic and antibiofilm potential. It is also easy to produce Se-based nanocomposites. For instance, Jin et al. prepared SeNPs embedded and homogeneously dispersed in black fungus-extracted BFP nanotubes (triple helix $\beta-(1,3)$-D-glucan) that possess hydrophilic hydroxyl groups. These nanocomposites showed interesting cytotoxic and antitumor properties [188]. 


\subsection{Using Yeast}

Yeast is a relevant model system to investigate the metabolic detoxification pathways of selenite/selenate and their conversion to selenomethionine [202,203]. Thus, Se-rich yeasts are used as a food supplement because they accumulate up to $3000 \mathrm{ppm}$ of selenium [203] and can be used as a cancer treatment at elevated doses ( $>200 \mu \mathrm{g}$ Se per day) [204]. However, further analyses are needed to identify and quantify the chemical forms of selenium should these Se-rich yeasts be commercialized. For example, Jiménez-Lamana et al. used single particle inductively coupled plasma mass spectrometry (SP-ICPMS) to detect, characterize, and quantify putative nanoparticles in Se-rich yeasts [205]. Bartosiak et al. calculated the accurate yield of SeNP synthesis mediated by Saccharomyces boulardii using continuous photochemical vapor generation (PCVG) coupled with microwave-induced plasma optical emission spectrometry (MIP-OES) and UV-Vis spectrophotometry (PCVG-MIP-OES) [206]. This efficient method enabled the selective identification and quantification of both the unreacted Se(IV) and the final water-soluble SeNPs without the need to separate them. Lian et al. synthesized spherical and quasispherical SeNPs of 70-90 nm in size utilizing the yeast cell-free extract of Magnusiomyces ingens LH-F1; some surface proteins played a significant role during the synthesis, acting as reducing or capping agents [207]. Nevertheless, the mechanisms of SeNP formation are not fully understood.

S. cerevisiae primarily reduces selenium ions through metabolism [208,209]. Owing to its high selenium tolerance, $S$. cerevisiae constitutes a promising and cost-effective alternative for the removal of selenium ions from aqueous solutions [210]. Additionally, it is postulated that SeNPs are expelled from $S$. cerevisiae cells by vesicle-like structures under microaerophilic conditions followed by the ulterior capping of these NPs with residual organic components from the vesicle-like structures [211]. As the SeNPs are stabilized by the natural organic molecules of yeast cultures, there is no need for additional stabilizing agents [206].

The reduction of selenite/selenate to elemental selenium in yeasts forms SeNPs either extra- or intracellularly. In intracellular routes, a genetically engineered, metalresistant Pichia pastoris clone carrying Cyb5R gene has been found to be a safe bioreactor to produce homogeneous and stable selenium and silver NPs. This yeast used a versatile and simple mechanism of biosorption and biotransformation of metals with less toxic waste than physicochemical synthesis [50]. On the other hand, the extracellular processes have the advantage of easy biogenic NP recovery over their intracellular counterparts [211]. According to Rassouli, the general procedure for the extraction and purification of yeastproduced SeNPs consists of (i) applying some enzymatic, chemical, or mechanic method to destroy the cell wall; (ii) collecting the biomass by centrifugation at $8000 \mathrm{rpm}$ for $10 \mathrm{~min}$; (iii) crushing the cells using liquid nitrogen and ultrasounds; (iv) incubating the broken cells with added buffer at $60{ }^{\circ} \mathrm{C}$ for $10 \mathrm{~min}$; (v) mixing the pellet containing the cell fragments and NPs with octanol and distilled water to give rise to two phases of which (vi) the SeNP-containing top phase is recovered and further washed with ethanol and chloroform [48].

\section{Microbial Synthesis of Tellurium Nanoparticles}

Tellurium is highly toxic to living beings and is not essential in biological metabolism. This may explain why TeNP biosynthesis using microbes is more limited when compared to SeNP [212]. Few articles have been published that detail the biosynthesis of TeNPs using microorganisms (Figure 4) [51,97,213-219]. Generally, $\mathrm{K}_{2} \mathrm{TeO}_{3}$ or $\mathrm{Na}_{2} \mathrm{TeO}_{3}$ precursors are used to produce TeNPs since they are least toxic when compared to other precursors [97,212,220-222]. Tellurium has different oxidation states: telluride $\left(\mathrm{Te}^{2-}\right)$, tellurite $\left(\mathrm{TeO}_{3}{ }^{2-}\right)$, tellurate $\left(\mathrm{TeO}_{4}{ }^{2-}\right)$. In general, the agglomeration of $\mathrm{Te}(0)$ is associated with the respiration of the microorganisms, such as yeast (S. cerevisiae), where the fermentation increases the production [223]. On the other hand, a decrease in NP production is observed in bacteria when the oxygen is limited [213]. 


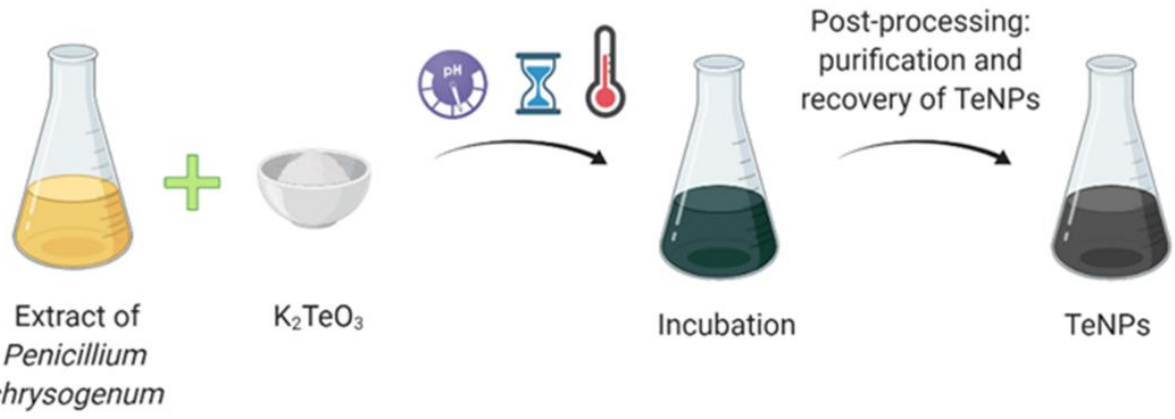

Figure 4. Tellurium nanoparticles (TeNPs) synthesis using microorganisms.

Considering that tellurium is in the same group as selenium, Yang et al. studied the antioxidant activity of TeNPs recovered from tellurium-enriched Spirulina platensis cultures where tellurium interacts with two phycobiliproteins, the phycocyanin (Te-PC) and allophycocyanin (Te-APC) (Figure 5) [224].

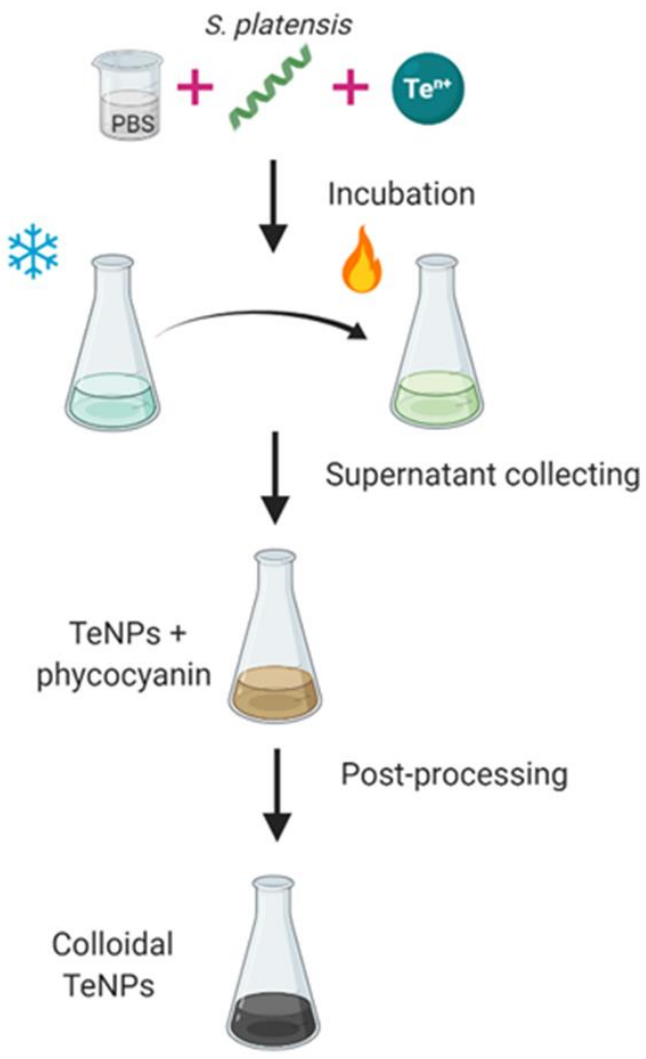

Figure 5. Purification of tellurium-containing phycocyanin (Te-PC) and allophycocyanin (Te-APC) from Te-enriched S. platensis using a chromatographic method.

From a mechanistic point-of-view, a correlation has been established between the growth, size, and shape of TeNPs and the proteins and enzymes present in the media, in addition to other small molecules, such as pyruvate, lactate, and NADH $[51,213,225]$. Furthermore, the formation of elemental tellurium can be inhibited by other molecules, such as nitrate, nitrite, and fumarate [226]. Since the conditions affecting the TeNP formation can vary as a function of the used organism, there are also great variations in microbe growth time (1-9 days), precursor concentrations (12-600 $\left.\mathrm{mg} \mathrm{L}^{-1}\right)$, and reaction time (1-8 days). 


\section{Plant-Mediated Synthesis of Metalloid Nanoparticles}

Phytonanotechnology is of special interest for synthesizing SeNPs since it is a simple, eco-friendly, high-throughput, and inexpensive route [227-229]. The biofabrication of NPs via plants involves proteins, amino acids, organic acids, vitamins, as well as secondary metabolites that act as reducers and stabilizers, such as polysaccharides, alkaloids, flavonoids, phenols, saponins, quinine, steroids, and glycosides [230,231]. Plant-mediated NP synthesis may be carried out through two ways. Via the in vivo route, the NP morphology and size depend strongly on the biosynthesis location, e.g., roots, leaves, fruits, peels, buds, etc., and the implicated metabolites [27]. A chelation-mediated detoxification faculty may explain the mechanism of NP synthesis [232]. The enzymatic antioxidant system is also activated to provide a reactive oxygen species (ROS) balance [233]. Generally, inorganic Se salts (selenite and selenate) taken up by plants are biotransformed into organic Se forms, such as SeCys2, SeMet, and MeSeCys bounded with proteins [234,235]. Hu et al. demonstrated the bioavailability of SeNPs in roots and shoots where they could be biotransformed into organic Se compounds, selenite and selenate to generate Se-biofortified plants [236]. However, the in vitro synthesis using plant extracts is better since it eliminates the lengthy process of cultivation, but still allows for screening the experimental parameters, such as the biomass choice, extraction process and amount, the $\mathrm{pH}$, and temperature [237].

\subsection{Plant-Based Synthesis of Selenium Nanoparticles}

Several papers have reported the plant-derived biosynthesis of SeNPs with varying sizes and morphologies (Table 3). For instance, Hibiscus sabdariffa fabricated spherical, triangular, and hexagonal SeNPs with a size of $20-50 \mathrm{~nm}$ [238] whereas Azadirachta indica has been used as a rapid and efficient biosystem to produce crystalline and spherical SeNPs with a smooth surface [239]. Withania somnifera was the best adaptogen herb with active withanolide and flavonoids, used as a bioreductant system to fabricate SeNPs of $40-90 \mathrm{~nm}$ [240]. Although plants offer the most suitable green synthesis protocols, the mode of action of plant-produced SeNPs against bacteria remains unknown; it is suggested that the nanoparticles interact with the peptidoglycan layer and break up the bacterial cell wall [227]. Besides, SeNPs are able to induce apoptosis or programmed cell death [174]. Anu et al. reported spherical SeNPs produced by a cheap aqueous extract of garlic cloves, Allium sativum, that acted as both the reducing and capping agent [241]. These biogenic SeNPs showed lower cytotoxicity against the Vero cell line than those chemically synthesized. The same group took advantage of the medicinal properties of Cassia auriculata to synthesize functional SeNPs that displayed interesting anticancer and antiproliferative characteristics [241]. Similar studies have reported the use of Vitis vinifera [32], broccoli extract [108], and Capsicum annum [242] to fabricate Se nanorods and nanoballs. Importantly, Ramamurthy et al. presented a combination of SeNPs, made using fenugreek seed extract, and doxorubicin to form a chemoprotective agent against cancer [243]; Vennila et al. studied the antibacterial, anticancer, and anti-inflammatory activity of SeNPs biofabricated by Spermacoce hispida and functionalized with apigenin, quinoline, quinazoline, and synaptogenin B [244]; Kokila et al. reported on Se-NPs using the leaves of Diospyros montana as a biocidal agent against both Gram + S. aureus and Gram- E. coli and the fungus A. niger [245].

Table 3. Different species of plants used for the biosynthesis of SeNPs.

\begin{tabular}{ccccccc}
\hline Plant Species & Part & Metabolites & Shape & Size (nm) & Activity/Application & Ref. \\
\hline Withania somnifera & Leaves & $\begin{array}{c}\text { Flavonoids } \\
\text { Phenolics } \\
\text { Tannins }\end{array}$ & Spherical & $40-90$ & $\begin{array}{c}\text { Antibacterial } \\
\text { Antioxidant } \\
\text { Anticancer }\end{array}$ & $\begin{array}{c}\text { [240] } \\
\text { Psidium guajava }\end{array}$ \\
\hline Allium sativum & Leaves & N/A & Spherical & $8-20$ & Antibacterial & [227] \\
\hline
\end{tabular}


Table 3. Cont.

\begin{tabular}{|c|c|c|c|c|c|c|}
\hline Plant Species & Part & Metabolites & Shape & Size $(\mathrm{nm})$ & Activity/Application & Ref. \\
\hline Cassia auriculata & Leaves & $\mathrm{N} / \mathrm{A}$ & Amorphous & $10-20$ & Anti-leukemia & [237] \\
\hline Momordica charantia & $\begin{array}{l}\text { Roots and } \\
\text { shoots }\end{array}$ & $\begin{array}{c}\text { Terpenoids } \\
\text { Phenolics }\end{array}$ & Spherical & $10-30$ & $\begin{array}{l}\text { Toxicological } \\
\text { studies }\end{array}$ & [246] \\
\hline Hawthorn fruit & Fruit & $\mathrm{N} / \mathrm{A}$ & Spherical & 113 & Antitumor & [247] \\
\hline Hibiscus sabdariffa & Leaves & $\begin{array}{l}\text { Phenols } \\
\text { Alcohols }\end{array}$ & $\begin{array}{l}\text { Spherical } \\
\text { Triangular } \\
\text { Hexagonal }\end{array}$ & $20-50$ & Antioxidant & [238] \\
\hline Pelargonium zonale & Leaves & $\mathrm{N} / \mathrm{A}$ & Spherical & $40-60$ & $\begin{array}{c}\text { Antibacterial } \\
\text { Antifungal }\end{array}$ & [248] \\
\hline Aloe vera & Leaves & $\begin{array}{l}\text { Hydroxyls } \\
\text { Amides }\end{array}$ & Spherical & $121-3243$ & $\begin{array}{c}\text { Antibacterial } \\
\text { Antifungal }\end{array}$ & [249] \\
\hline Emblica officinali & Fruit & $\begin{array}{l}\text { Phenolics } \\
\text { Flavonoids } \\
\text { Tannins }\end{array}$ & Spherical & $20-60$ & Antimicrobial & [228] \\
\hline Moringa oleifera & Leaves & $\begin{array}{l}\text { Phenolics } \\
\text { Flavones }\end{array}$ & Spherical & $23-35$ & Anticancer & [250] \\
\hline Triticum aestivum & Roots & $\mathrm{N} / \mathrm{A}$ & Spherical & $140 \pm 40$ & Biofertilizer & [236] \\
\hline Broccoli & $\mathrm{N} / \mathrm{A}$ & $\begin{array}{l}\text { Carotenes } \\
\text { Glucosinolates } \\
\text { Polyphenols }\end{array}$ & Spherical & 50-150 & $\begin{array}{l}\text { Antioxidant } \\
\text { Anticancer }\end{array}$ & [108] \\
\hline Diospyros montana & Leaves & $\begin{array}{l}\text { Phenolics } \\
\text { Flavonoids }\end{array}$ & Spherical & $4-16$ & $\begin{array}{l}\text { Antibacterial } \\
\text { Anticancer }\end{array}$ & [245] \\
\hline Ocimum tenuiflorum & Leaves & Polyphenols & Spherical & $15-20$ & $\begin{array}{c}\text { Inhibition of } \\
\text { nephrolithiasis }\end{array}$ & [183] \\
\hline Theobroma cacao & Shell & $\begin{array}{c}\text { Polysaccharides } \\
\text { Proteins } \\
\text { Phenolics }\end{array}$ & $\begin{array}{l}\text { Spherical } \\
\text { Trigonal }\end{array}$ & $1-3$ & $\mathrm{~N} / \mathrm{A}$ & [251] \\
\hline Zingiber officinale & Roots & $\begin{array}{l}\text { Flavonoids } \\
\text { Terpenoids }\end{array}$ & Spherical & $100-150$ & $\begin{array}{c}\text { Antimicrobial } \\
\text { Antioxidant }\end{array}$ & [252] \\
\hline Mucuna pruriens & Seed & Phytochemicals & $\begin{array}{l}\text { Spherical } \\
\text { Nanorods }\end{array}$ & $100-120$ & $\begin{array}{l}\text { Antioxidant } \\
\text { Anticancer }\end{array}$ & [102] \\
\hline Azadirachta indica & Leaves & $\begin{array}{l}\text { Polyphenols } \\
\text { Flavonoids } \\
\text { Proteins }\end{array}$ & Spherical & $\begin{array}{l}142-168 \\
221-328\end{array}$ & Antibacterial & [239] \\
\hline Vitis vinifera & $\mathrm{N} / \mathrm{A}$ & Lignin & Spherical & $3-18$ & $\mathrm{~N} / \mathrm{A}$ & [32] \\
\hline Clausena dentata & Leaves & $\begin{array}{l}\text { Flavonoids } \\
\text { Triterpenoids } \\
\text { Polyphenols }\end{array}$ & Spherical & $46-79$ & Larvicidal & [229] \\
\hline Spermacoce hispida & Leaves & $\begin{array}{l}\text { Polyols } \\
\text { Saponins }\end{array}$ & Rod-shaped & $120 \pm 15$ & $\begin{array}{c}\text { Anti-inflammatory } \\
\text { Antibacterial } \\
\text { Anticancer }\end{array}$ & [244] \\
\hline Rosa roxburghii & $\mathrm{N} / \mathrm{A}$ & $\begin{array}{l}\text { Polysaccharide } \\
\text { (RTFP-3) }\end{array}$ & Spherical & 105 & Antioxidant & [253] \\
\hline Lycium barbarum & Berries & $\begin{array}{l}\text { Flavonols } \\
\text { (catechins) }\end{array}$ & $\begin{array}{l}\text { Spherical } \\
\text { Triangular }\end{array}$ & $83-160$ & Antioxidant & [254] \\
\hline Fenugreek & Seeds & $\begin{array}{l}\text { Phenol } \\
\text { Flavonol }\end{array}$ & Oval & 50-150 & Anticancer & [243] \\
\hline Allium sativum & Bulbs & $\begin{array}{l}\text { Alcohols } \\
\text { Phenols }\end{array}$ & Spherical & 205 & $\begin{array}{l}\text { Antioxidant } \\
\text { Anticancer }\end{array}$ & [255] \\
\hline
\end{tabular}


The application of SeNPs in toxicological studies is relevant due to their association with DNA cytosine methylation, chromatin structure, and transcription processes. It is advantageous for the manipulation and study of cellular division, tissue differentiation, metabolism, and transcription programs [246]. Cui et al. (2018) reported on the production of monodispersed and stable SeNPs from hawthorn fruit extract (HE-SeNPs) whose antitumor activity was evidenced by the apoptosis induced in HepG2 cells through the overproduction of intracellular ROS and mitochondrial membrane potential (MMP) loss or disruption [247]. Additionally, HE-SeNPs induced the upregulation of caspase-9 and downregulation of Bcl-2. Fardsadegh et al. detailed the hydrothermal synthesis of SeNPs using Aloe vera leaf extract and determined a prediction model and optimal conditions using response surface methodology (RSM) [249].

\subsection{Plant-Based Synthesis of Tellurium Nanoparticles}

Tellurium is not essential for plant metabolism besides being toxic in most cases [256]. Despite this, it has been documented that some plants have the ability to metabolize Te and transform it into telluroamino acids [257] and organotellurium [258]. A. sativum, commonly known as garlic, can assimilate chalcogens to give rise to Te-methyltellurocysteine (MeTeCys) and S-methyltellurosulfide metabolites [256]. The TeNP size is found to be 40-55 nm. The majority of these metabolites were found highly concentrated at the tips of their gloves and in the initial part of the roots. In some cases, TeNPs produced by plants may appear as spheres, rod-shaped, and plates [259].

\section{Biosynthesis of Bimetallic Se-Te Alloy Nanoparticles}

Bimetallic Se-Te alloy NPs possess unique and enhanced properties including optical, semiconductive electroresistance, and magnetoresistance [90,260,261]. A few studies have reported the bacterial synthesis of Se-Te nanostructures by B. beveridgei [262] and soil isolates of heterotrophic aerobic bacteria [263]. The simultaneous formation of trigonalhexagonal $\mathrm{Se}(0)-\mathrm{Te}(0)$ nanostructures from the bioreduction of Se and Te oxyanions in a lab-scale upflow anaerobic sludge blanket reactor (UASB) was also described [149]. A layer of extracellular polymeric substances (EPS) capped the nanoparticles to immobilize them in the granular sludge. Besides crystalline hexagonal TeNPs, the fungus Phanerochaete chrysosporium biofabricated unique Se-Te nanospheres and needle-like nanoparticles of 500-600 nm (Figure 6) [65].

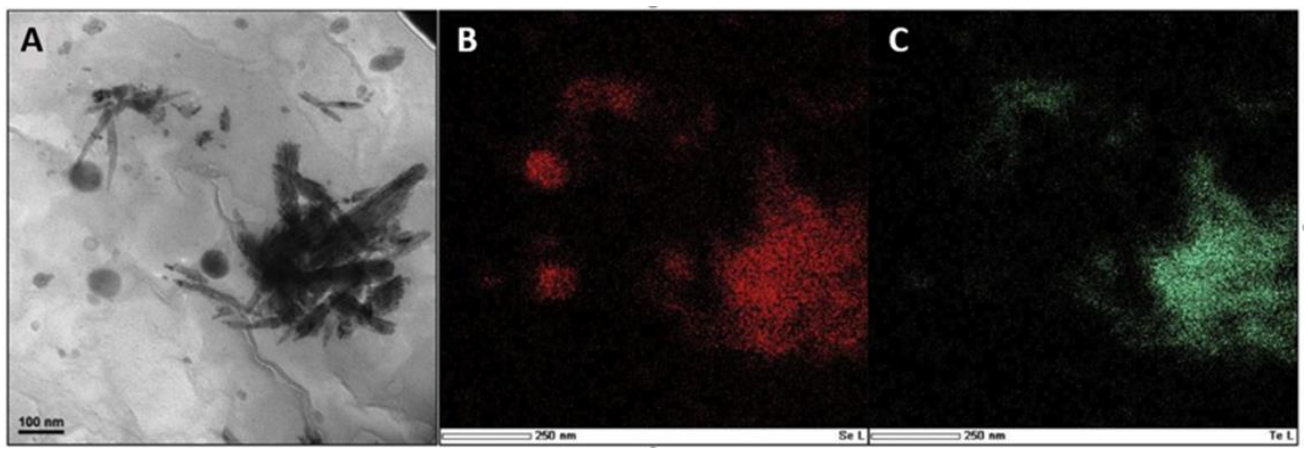

Figure 6. (A) TEM image of the hyphae of Phanerochaete chrysosporium that depicts Se-Te alloy NPs. STEM-EDS elemental mapping for Se (B) and Te (C) that confirms the alloy character of these Se-Te NPs. Adapted from [65] with permission from Elsevier.

Additionally, Asghari-Paskiabi et al. reported the formation of stable Se-S NPs inside S. cerevisiae [209]; Vogel et al. investigated the extracellular synthesis of Se-S NPs by Azospirillum brasilense mainly attributable to the high negative surface charge due to the covering organic layer made of proteins and carbohydrates [125]. 


\section{Bioapplications of SeNPs and TeNPs}

In the field of nanobiotechnology, nanoparticles represent the core of a nano-biomaterial; they can be functionalized with different moieties to reduce the toxicity and improve the effects of the drugs [264-266]. Moreover, nanoparticles can be used for various medical, industrial, or biological applications. For instance, in nanomedicine, a wide number of surface structures to functionalize the NP surface have been developed for imaging, sensing, and drug delivery applications [267]; the as-obtained NPs can be used for the detection of pathogens and biomolecules or the hyperthermia treatment of cancer [268].

Nanoscale selenium has attracted the attention of scientists due to its bioavailability and lower toxicity compared to the other forms of selenium [269]. Gao et al. studied the antioxidant properties of SeNPs and demonstrated the reduced risk of selenium toxicity [187]. Moreover, SeNPs can be used as an antioxidant in food additives due to their lower risk of toxicity. Besides their antioxidant activity, SeNPs are also an excellent chemopreventive agent against cancer as well as a potential anticancer drug [270]. Specifically, the efficacy and specificity of using nanoselenium at a concentration as low as $2 \mu \mathrm{g} \mathrm{mL}^{-1}$ against prostate cancer has been reported [174]. Other studies highlighted the antimicrobial properties [114] and antifungal activity [271] of SeNPs.

The antimicrobial, antioxidant, antifungal, and anticancer properties of TeNPs have been well documented. For instance, Shakibaie et al. described the antioxidant and antimicrobial properties of biologically synthesized tellurium nanorods (TeNRs) [272] Moreover, another study reveals the antimicrobial and anticancer properties of citrus juice-mediated synthesized TeNPs [62] while the S. baltica-synthesized TeNRs exhibit an excellent photocatalytic and anti-biofilm activity to counter potential human pathogens [59]. The next graphic summarizes the main applications of SeNPs and TeNPs (Figure 7).

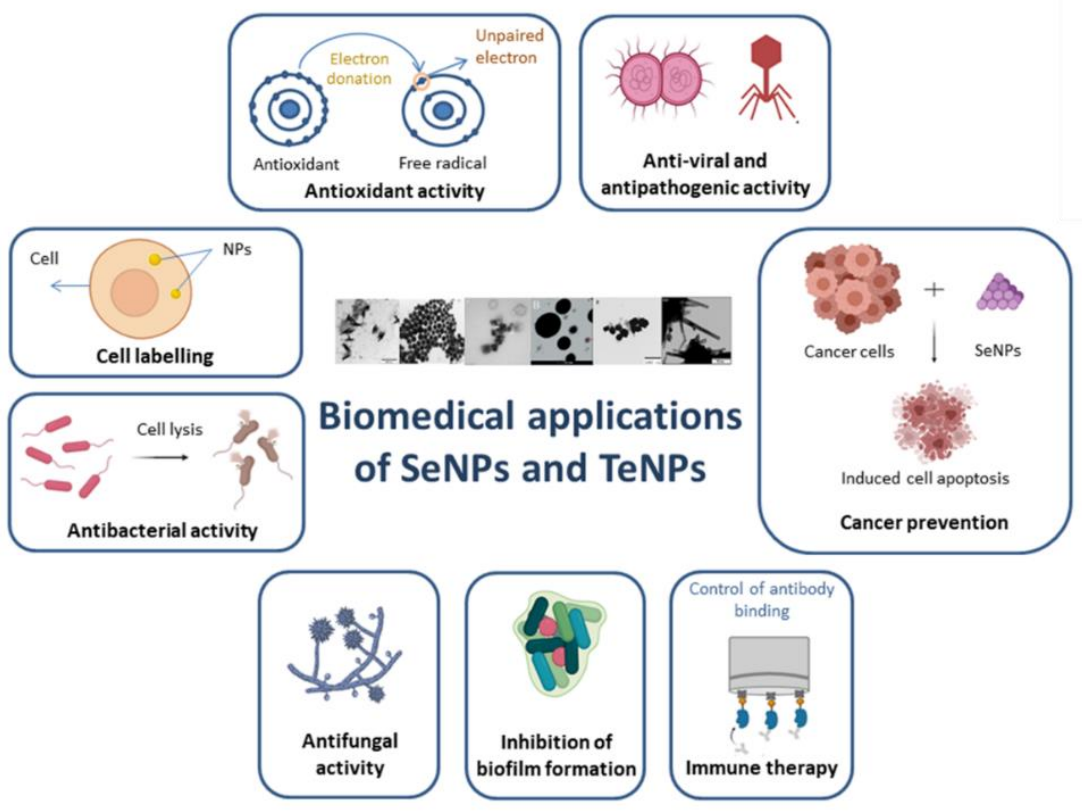

Figure 7. Schematic representation of the various bioapplications of biogenic SeNPs and TeNPs.

\section{Human Cell-Cytotoxicity and Immune Response Induced by SeNPs and TeNPs}

According to several studies, various nanoparticles may be cytotoxic and cause harmful effects or even irreversible damage to human cells [264,265]. Therefore, it is necessary to determine how synthesized nanoparticles affect the immune cells [273-275]. Selenium nanomaterials have attracted considerable attention as a novel anticancer and chemopreventive agent due to their exceptional biocompatibility and low toxicity [276]. For instance, Cremonini et al. studied the effect of biogenic SeNPs synthesized using Stenotrophomonas maltophilia (-) and B. mycoides (+) on the viability and function of the 
antigen-presenting cells, DCs, and cultured fibroblasts (nonimmune cells) [114]. As a result, the as-produced SeNPs did not cause any damage to human cells since there was no stimulation or increase in the release of proinflammatory and immunostimulatory cytokines including IL-12, IL-6, IL-8, and TNF- $\alpha$. Other studies indicate the SeNPs synthesized by bacteria can induce apoptosis or inhibit both growth and proliferation of cancer cells in culture [276-279]. SeNPs synthesized by Acinetobacter sp. SW30 seem to display a greater anticancer activity when compared to their chemically synthesized counterparts; in fact, they reveal a strong antiproliferative activity against 4T1 cells, MCF-7, NIH/3T3, and HEK293 cell lines [58]. SeNPs synthesized by B. oryziterrae also showed potential anticancer activity against $\mathrm{H} 157$ lung cancer cell lines [280].

An assay carried out using the SeNPs produced by Bacillus sp. MSh-1 against the human fibrosarcoma cell line (HT-1080) demonstrated that the higher the concentration, the higher the cytotoxicity [117]. Moreover, the same study showed the anti-invasive property of HT-1080 cells and the moderate inhibition of MMP-2 expression, a good insight for the treatment and prevention of tumor metastasis. The MTT assay has been used to assess the cell viability, proliferation, and cytotoxicity of breast cancer cells.

One possible explanation for the anticancer activity of SeNPs was reported by Ahmed et al. which encompasses the mobilization of endogenous copper, possibly chromatinbound copper, and the subsequent prooxidant action [276]. The authors suggested that cancer cells are more subject to electron shuttling between copper ions and selenium nanostructures which release reactive oxygen species (ROS) and thereby kill cancer cells such as Hep-G2 and MCF-7 cell lines. The precise mechanism of anticarcinogenic actions of SeNPs is not totally understood. Since it possesses a high bioactivity and represents the major component of selenoproteins, selenium may increase the carcinogen detoxification, inhibit tumor cell invasion and angiogenesis, enhance immune surveillance, and provide antioxidant protection [281-283].

The cytotoxic effects of biosynthesized TeNPs have also been investigated due to their ability to act as an anticancer and antiviral agent [283-285]. For instance, Forootanfar et al. demonstrated the lower cytotoxic effect of biogenic TeNRs compared to potassium tellurite on four cell lines of MCF-7, HT1080, HepG2, and A549 [286]. Overall, the toxicity of Te nanostructures depends on the employed synthesis method and their size/morphology [287].

\section{Conclusions and Perspectives}

The present review extensively describes different green methodologies used for the biofabrication of SeNPs and TeNPs. A variety of microorganisms, such as bacteria, fungi and yeast, and plant extracts have become novel, sustainable, risk-free, and cost-effective bionanofactories that reduce selenite/selenate and tellurite/tellurate into their nanosized zero-valent counterparts. To achieve simple, fast, and efficient biological syntheses, these eco-friendly procedures leverage the different organic molecules and metabolites that act as reducing, chelating, and stabilizing agents, such as proteins, EPS, lipids, flavonoids, phenols, and alcohols. The bioreduction and biotransformation of different Se and/or Te species into elemental Se/Te have emerged as an important pursuit in biomedicine, chemistry, nanotechnology, and engineering. Some experimental parameters including the $\mathrm{pH}$, temperature, reaction time, and precursor concentration, along with biosurfactants, play an active role in determining the shape, size, crystallinity, dispersion, and properties of the as-obtained metalloid NPs. This review found that most of the biogenic SeNPs were spherical while their TeNP counterparts were rod-shaped; this constitutes a remarkable outcome in bionanotechnology. However, it is necessary to carry out deeper research on the specifically involved production and transformation mechanisms. Although the toxicity effect of bioresources (i.e., plants) or the nanoparticles synthesized have not been fully explored yet, green production opens up opportunities to manufacture safer nanomaterials and foster better understanding of safety, health, and environment issues. 
A myriad of literature shows research at the laboratory scale using living or dead biomass. An important challenge lies in developing large-scale production processes, where larger amounts of templates, surfactants, and other auxiliary substances are required. Then, the use of continuous-flow microreactors and other sources such as waste materials and algae/microalgae may provide significant advantages for industrial level and nanotechnology applications. The development of greener methods that enhance the bioavailability, longevity, and composition-control of NPs could be carried out by computational, synthetic biology and genetic engineering techniques. The employment of natural "nanofactories" is still at an early stage; however, further research would enable the development of straightforward approaches to create potential solutions in nanomedicine, biomedical devices, energy crises, water pollution, and optoelectronics.

Funding: This research received no external funding.

Conflicts of Interest: The authors declare no conflict of interest.

\section{References}

1. Hosnedlova, B.; Kepinska, M.; Skalickova, S.; Fernandez, C.; Ruttkay-Nedecky, B.; Peng, Q.; Baron, M.; Melcova, M.; Opatrilova, R.; Zidkova, J.; et al. Nano-selenium and its nanomedicine applications: A critical review. Int. J. Nanomed. 2018, 13, 2107-2128. [CrossRef]

2. Li, X.; Xu, H.; Chen, Z.-S.; Chen, G. Biosynthesis of Nanoparticles by Microorganisms and Their Applications. J. Nanomater. 2011, 2011, 270974. [CrossRef]

3. Rashidi, L.; Khosravi-Darani, K. The applications of nanotechnology in food industry. Crit. Rev. Food Sci. Nutr. 2011, 51, 723-730. [CrossRef] [PubMed]

4. Stark, W.J.; Stoessel, P.R.; Wohlleben, W.; Hafner, A. Industrial Applications of Nanoparticles. Chem. Soc. Rev. 2015, 44, 5793-5805. [CrossRef] [PubMed]

5. Singh, R.; Nalwa, H.S. Medical applications of nanoparticles in biological imaging, cell labeling, antimicrobial agents, and anticancer nanodrugs. J. Biomed. Nanotechnol. 2011, 7, 489-503. [CrossRef] [PubMed]

6. Sakr, T.M.; Korany, M.; Katti, K.V. Selenium nanomaterials in biomedicine-An overview of new opportunities in nanomedicine of selenium. J. Drug Deliv. Sci. Technol. 2018, 46, 223-233. [CrossRef]

7. Brito-Silva, A.M.; Gómez, L.A.; de Araújo, C.B.; Galembeck, A. Laser Ablated Silver Nanoparticles with Nearly the Same Size in Different Carrier Media. J. Nanomater. 2010, 2010, 142897. [CrossRef]

8. Nee, C.H.; Yap, S.L.; Tou, T.Y.; Chang, H.C.; Yap, S.S. Direct synthesis of nanodiamonds by femtosecond laser irradiation of ethanol. Sci. Rep. 2016, 6, 33966. [CrossRef]

9. Anbarasu, M.; Anandan, M.; Chinnasamy, E.; Gopinath, V.; Balamurugan, K. Synthesis and characterization of polyethylene glycol (PEG) coated $\mathrm{Fe}_{3} \mathrm{O}_{4}$ nanoparticles by chemical co-precipitation method for biomedical applications. Spectrochim. Acta A Mol. Biomol. Spectrosc. 2015, 135, 536-539. [CrossRef]

10. Janjua, M.R.S.A. Synthesis of $\mathrm{Co}_{3} \mathrm{O}_{4}$ Nano Aggregates by Co-precipitation Method and its Catalytic and Fuel Additive Applications. Open Chem. 2019, 17, 865-873. [CrossRef]

11. Li, M.; Gu, L.; Li, T.; Hao, S.; Tan, F.; Chen, D.; Zhu, D.; Xu, Y.; Sun, C.; Yang, Z. TiO 2 -Seeded Hydrothermal Growth of Spherical

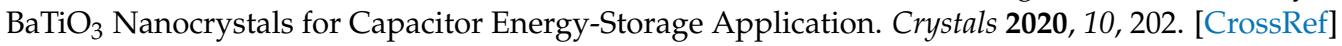

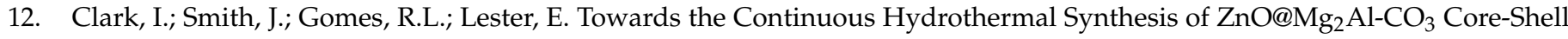
Composite Nanomaterials. Nanomaterials 2020, 10. [CrossRef] [PubMed]

13. Cheng, G.; Yang, H.; Rong, K.; Lu, Z.; Yu, X.; Chen, R. Shape-controlled solvothermal synthesis of bismuth subcarbonate nanomaterials. J. Solid State Chem. 2010, 183, 1878-1883. [CrossRef]

14. Yang, S.; Zhou, X.; Zhang, J.; Liu, Z. Morphology-controlled solvothermal synthesis of $\mathrm{LiFePO}_{4}$ as a cathode material for lithium-ion batteries. J. Mater. Chem. 2010, 20, 8086-8091. [CrossRef]

15. Riccò, R.; Nizzero, S.; Penna, E.; Meneghello, A.; Cretaio, E.; Enrichi, F. Ultra-small dye-doped silica nanoparticles via modified sol-gel technique. J. Nanopart. Res. 2018, 20. [CrossRef] [PubMed]

16. Adnan, R.; Razana, N.A.; Abdul Rahman, I.; Farrukh, M.A. Synthesis and Characterization of High Surface Area Tin Oxide Nanoparticles via the Sol-Gel Method as a Catalyst for the Hydrogenation of Styrene. J. Chin. Chem. Soc. 2010, 57, 222-229. [CrossRef]

17. Brayner, R.; Dahoumane, S.A.; Nguyen, J.N.; Yepremian, C.; Djediat, C.; Coute, A.; Fievet, F. Ecotoxicological studies of CdS nanoparticles on photosynthetic microorganisms. J. Nanosci. Nanotechnol. 2011, 11, 1852-1858. [CrossRef]

18. Brayner, R.; Dahoumane, S.A.; Yepremian, C.; Djediat, C.; Meyer, M.; Coute, A.; Fievet, F. ZnO nanoparticles: Synthesis, characterization, and ecotoxicological studies. Langmuir 2010, 26, 6522-6528. [CrossRef]

19. Khaydarov, R.A.; Khaydarov, R.R.; Gapurova, O.; Estrin, Y.; Scheper, T. Electrochemical method for the synthesis of silver nanoparticles. J. Nanopart. Res. 2008, 11, 1193-1200. [CrossRef]

20. Starowicz, M.; Starowicz, P.; Zukrowski, J.; Przewoznik, J.; Lemanski, A.; Kapusta, C.; Banas, J. Electrochemical synthesis of magnetic iron oxide nanoparticles with controlled size. J. Nanopart. Res. 2011, 13, 7167-7176. [CrossRef] 
21. Armijo Garcia, D.; Mendoza, L.; Vizuete, K.; Debut, A.; Arias, M.T.; Gavilanes, A.; Terencio, T.; Avila, E.; Jeffryes, C.; Dahoumane, S.A. Sugar-Mediated Green Synthesis of Silver Selenide Semiconductor Nanocrystals under Ultrasound Irradiation. Molecules 2020, 25. [CrossRef]

22. Yan, Q.; Qiu, M.; Chen, X.; Fan, Y. Ultrasound Assisted Synthesis of Size-Controlled Aqueous Colloids for the Fabrication of Nanoporous Zirconia Membrane. Front. Chem. 2019, 7, 337. [CrossRef] [PubMed]

23. Kumar, S.V.; Bafana, A.P.; Pawar, P.; Faltane, M.; Rahman, A.; Dahoumane, S.A.; Kucknoor, A.; Jeffryes, C.S. Optimized production of antibacterial copper oxide nanoparticles in a microwave-assisted synthesis reaction using response surface methodology. Colloid Surf. A Physicochem. Eng. Aspect 2019, 573, 170-178. [CrossRef]

24. Bafana, A.; Kumar, S.V.; Temizel-Sekeryan, S.; Dahoumane, S.A.; Haselbach, L.; Jeffryes, C.S. Evaluating microwave-synthesized silver nanoparticles from silver nitrate with life cycle assessment techniques. Sci. Total Environ. 2018, 636, 936-943. [CrossRef] [PubMed]

25. Gomez-Gomez, B.; Arregui, L.; Serrano, S.; Santos, A.; Perez-Corona, T.; Madrid, Y. Selenium and tellurium-based nanoparticles as interfering factors in quorum sensing-regulated processes: Violacein production and bacterial biofilm formation. Metallomics 2019, 11, 1104-1114. [CrossRef]

26. Dahoumane, S.A.; Jeffryes, C.; Mechouet, M.; Agathos, S.N. Biosynthesis of Inorganic Nanoparticles: A Fresh Look at the Control of Shape, Size and Composition. Bioengineering 2017, 4, 14. [CrossRef]

27. Rahman, A.; Lin, J.; Jaramillo, F.E.; Bazylinski, D.A.; Jeffryes, C.; Dahoumane, S.A. In Vivo Biosynthesis of Inorganic Nanomaterials Using Eukaryotes-A Review. Molecules 2020, 25. [CrossRef]

28. Kumar, S.V.; Bafana, A.P.; Pawar, P.; Rahman, A.; Dahoumane, S.A.; Jeffryes, C.S. High conversion synthesis of $<10 \mathrm{~nm}$ starch-stabilized silver nanoparticles using microwave technology. Sci. Rep. 2018, 8, 5106. [CrossRef]

29. Rahman, A.; Kumar, S.; Bafana, A.; Lin, J.; Dahoumane, S.A.; Jeffryes, C. A Mechanistic View of the Light-Induced Synthesis of Silver Nanoparticles Using Extracellular Polymeric Substances of Chlamydomonas reinhardtii. Molecules 2019, 24. [CrossRef]

30. Ramani, M.; Ponnusamy, S.; Muthamizhchelvan, C.; Marsili, E. Amino acid-mediated synthesis of zinc oxide nanostructures and evaluation of their facet-dependent antimicrobial activity. Colloid Surf. B Biointerfaces 2014, 117, 233-239. [CrossRef]

31. Manivasagan, P.; Oh, J. Marine polysaccharide-based nanomaterials as a novel source of nanobiotechnological applications. Int. J. Biol. Macromol. 2016, 82, 315-327. [CrossRef] [PubMed]

32. Sharma, G.; Sharma, A.R.; Bhavesh, R.; Park, J.; Ganbold, B.; Nam, J.S.; Lee, S.S. Biomolecule-mediated synthesis of selenium nanoparticles using dried Vitis vinifera (raisin) extract. Molecules 2014, 19, 2761-2770. [CrossRef] [PubMed]

33. Kuppusamy, P.; Yusoff, M.M.; Maniam, G.P.; Govindan, N. Biosynthesis of metallic nanoparticles using plant derivatives and their new avenues in pharmacological applications-An updated report. Saudi Pharm. J. 2016, 24, 473-484. [CrossRef] [PubMed]

34. Singh, P.; Kim, Y.J.; Zhang, D.; Yang, D.C. Biological Synthesis of Nanoparticles from Plants and Microorganisms. Trend Biotechnol. 2016, 34, 588-599. [CrossRef]

35. Jeffryes, C.; Agathos, S.N.; Rorrer, G. Biogenic nanomaterials from photosynthetic microorganisms. Curr. Opin. Biotechnol. 2015, 33, 23-31. [CrossRef]

36. Dahoumane, S.A.; Mechouet, M.; Wijesekera, K.; Filipe, C.D.M.; Sicard, C.; Bazylinski, D.A.; Jeffryes, C. Algae-mediated biosynthesis of inorganic nanomaterials as a promising route in nanobiotechnology-A review. Green Chem. 2017, 19, 552-587. [CrossRef]

37. Dahoumane, S.A.; Wujcik, E.K.; Jeffryes, C. Noble metal, oxide and chalcogenide-based nanomaterials from scalable phototrophic culture systems. Enzyme Microb. Technol. 2016, 95, 13-27. [CrossRef]

38. Dahoumane, S.A.; Djediat, C.; Yéprémian, C.; Couté, A.; Fiévet, F.; Brayner, R. Design of magnetic akaganeite-cyanobacteria hybrid biofilms. Thin Solid Film 2010, 518, 5432-5436. [CrossRef]

39. Dahoumane, S.A.; Yéprémian, C.; Djédiat, C.; Couté, A.; Fiévet, F.; Coradin, T.; Brayner, R. A global approach of the mechanism involved in the biosynthesis of gold colloids using micro-algae. J. Nanopart. Res. 2014, 16. [CrossRef]

40. Dahoumane, S.A.; Yéprémian, C.; Djédiat, C.; Couté, A.; Fiévet, F.; Coradin, T.; Brayner, R. Improvement of kinetics, yield, and colloidal stability of biogenic gold nanoparticles using living cells of Euglena gracilis microalga. J. Nanopart. Res. 2016, 18. [CrossRef]

41. Das, S.K.; Marsili, E. A green chemical approach for the synthesis of gold nanoparticles: Characterization and mechanistic aspect. Rev. Environ. Sci. Biotechnol. 2010, 9, 199-204. [CrossRef]

42. Gahlawat, G.; Roy Choudhury, A. A review on the biosynthesis of metal and metal salt nanoparticles by microbes. RSC Adv. 2019, 9, 12944-12967. [CrossRef]

43. Pantidos, N.; Horsfall, L.E. Biological Synthesis of Metallic Nanoparticles by Bacteria, Fungi and Plants. J. Nanomed. Nanotechnol. 2014, 5. [CrossRef]

44. Kitching, M.; Ramani, M.; Marsili, E. Fungal biosynthesis of gold nanoparticles: Mechanism and scale up. Microb. Biotechnol. 2015, 8, 904-917. [CrossRef] [PubMed]

45. Rahman, A.; Kumar, S.; Bafana, A.; Dahoumane, S.A.; Jeffryes, C. Biosynthetic Conversion of Ag(+) to highly Stable Ag(0) Nanoparticles by Wild Type and Cell Wall Deficient Strains of Chlamydomonas reinhardtii. Molecules 2019, 24, 98. [CrossRef]

46. Wang, D.; Xia, X.; Wu, S.; Zheng, S.; Wang, G. The essentialness of glutathione reductase GorA for biosynthesis of Se(0)nanoparticles and GSH for CdSe quantum dot formation in Pseudomonas stutzeri TS44. J. Hazard. Mater. 2019, 366, 301-310. [CrossRef]

47. Chaudhary, S.; Umar, A.; Mehta, S.K. Selenium nanomaterials: An overview of recent developments in synthesis, properties and potential applications. Prog. Mater. Sci. 2016, 83, 270-329. [CrossRef] 
48. Rasouli, M. Biosynthesis of selenium nanoparticles using yeast Nematospora coryli and examination of their anti-candida and anti-oxidant activities. IET Nanobiotechnol. 2019, 13, 214-218. [CrossRef]

49. Piacenza, E.; Presentato, A.; Zonaro, E.; Lampis, S.; Vallini, G.; Turner, R.J. Selenium and tellurium nanomaterials. Phys. Sci. Rev. 2018, 3. [CrossRef]

50. Elahian, F.; Reiisi, S.; Shahidi, A.; Mirzaei, S.A. High-throughput bioaccumulation, biotransformation, and production of silver and selenium nanoparticles using genetically engineered Pichia pastoris. Nanomed. Nanobiotechnol. 2017, 13, 853-861. [CrossRef]

51. Liang, X.; Perez, M.A.M.; Nwoko, K.C.; Egbers, P.; Feldmann, J.; Csetenyi, L.; Gadd, G.M. Fungal formation of selenium and tellurium nanoparticles. Appl. Microbiol. Biotechnol. 2019, 103, 7241-7259. [CrossRef] [PubMed]

52. Ramanujam, J.; Singh, U.P. Copper indium gallium selenide based solar cells-A review. Energy Environ. Sci. 2017, 10, 1306-1319. [CrossRef]

53. Tan, L.C.; Nancharaiah, Y.V.; Lu, S.; van Hullebusch, E.D.; Gerlach, R.; Lens, P.N.L. Biological treatment of selenium-laden wastewater containing nitrate and sulfate in an upflow anaerobic sludge bed reactor at pH 5.0. Chemosphere 2018, 211, 684-693. [CrossRef] [PubMed]

54. Schwarz, K.; Foltz, C.M. Selenium as an integral part of factor 3 against dietary necrotic liver degeneration. J. Am. Chem. Soc. 1957, 79, 3292-3293. [CrossRef]

55. Shoeibi, S.; Mashreghi, M. Biosynthesis of selenium nanoparticles using Enterococcus faecalis and evaluation of their antibacterial activities. J. Trace Elem. Med. Biol. 2017, 39, 135-139. [CrossRef] [PubMed]

56. Dhanjal, S.; Singh Cameotra, S. Aerobic biogenesis of selenium nanospheres by Bacillus cereus isolated from coalmine soil. Microbial. Cell Fact. 2010, 9, 52. [CrossRef]

57. Mohammed, E.T.; Safwat, G.M. Assessment of the ameliorative role of selenium nanoparticles on the oxidative stress of acetaminophen in some tissues of male albino rats. Beni-Suef Univ. J. Basic Appl. Sci. 2013, 2, 80-85. [CrossRef]

58. Wadhwani, S.A.; Gorain, M.; Banerjee, P.; Shedbalkar, U.U.; Singh, R.; Kundu, G.C.; Chopade, B.A. Green synthesis of selenium nanoparticles using Acinetobacter sp. SW30: Optimization, characterization and its anticancer activity in breast cancer cells. Int. J. Nanomed. 2017, 12, 6841-6855. [CrossRef]

59. Vaigankar, D.C.; Dubey, S.K.; Mujawar, S.Y.; D'Costa, A.; Shyama, S.K. Tellurite biotransformation and detoxification by Shewanella baltica with simultaneous synthesis of tellurium nanorods exhibiting photo-catalytic and anti-biofilm activity. Ecotoxicol. Environ. Saf. 2018, 165, 516-526. [CrossRef]

60. Huang, W.; Wu, H.; Li, X.; Chen, T. Facile One-Pot Synthesis of Tellurium Nanorods as Antioxidant and Anticancer Agents. Chem. Asian J. 2016, 11, 2301-2311. [CrossRef]

61. Medina Cruz, D.; Mi, G.; Webster, T.J. Synthesis and characterization of biogenic selenium nanoparticles with antimicrobial properties made by Staphylococcus aureus, methicillin-resistant Staphylococcus aureus (MRSA), Escherichia coli, and Pseudomonas aeruginosa. J. Biomed. Mater. Res. A 2018, 106, 1400-1412. [CrossRef] [PubMed]

62. Medina Cruz, D.; Tien-Street, W.; Zhang, B.; Huang, X.; Vernet Crua, A.; Nieto-Arguello, A.; Cholula-Diaz, J.L.; Martinez, L.; Huttel, Y.; Ujue Gonzalez, M.; et al. Citric Juice-mediated Synthesis of Tellurium Nanoparticles with Antimicrobial and Anticancer Properties. Green Chem. 2019, 21, 1982-1988. [CrossRef] [PubMed]

63. Vahidi, H.; Kobarfard, F.; Alizadeh, A.; Saravanan, M.; Barabadi, H. Green nanotechnology-based tellurium nanoparticles: Exploration of their antioxidant, antibacterial, antifungal and cytotoxic potentials against cancerous and normal cells compared to potassium tellurite. Inorg. Chem. Commun. 2021, 124, 108385. [CrossRef]

64. Mirjani, R.; Faramarzi, M.A.; Sharifzadeh, M.; Setayesh, N.; Khoshayand, M.R.; Shahverdi, A.R. Biosynthesis of tellurium nanoparticles by Lactobacillus plantarum and the effect of nanoparticle-enriched probiotics on the lipid profiles of mice. IET Nanobiotechnol. 2015, 9, 300-305. [CrossRef]

65. Espinosa-Ortiz, E.J.; Rene, E.R.; Guyot, F.; van Hullebusch, E.D.; Lens, P.N.L. Biomineralization of tellurium and seleniumtellurium nanoparticles by the white-rot fungus Phanerochaete chrysosporium. Int. Biodeter. Biodegr. 2017, 124, 258-266. [CrossRef]

66. Espinosa-Ortiz, E.J.; Rene, E.R.; van Hullebusch, E.D.; Lens, P.N.L. Removal of selenite from wastewater in a Phanerochaete chrysosporium pellet based fungal bioreactor. Int. Biodeter. Biodegr. 2015, 102, 361-369. [CrossRef]

67. Espinosa-Ortiz, E.J.; Pechaud, Y.; Lauchnor, E.; Rene, E.R.; Gerlach, R.; Peyton, B.M.; van Hullebusch, E.D.; Lens, P.N. Effect of selenite on the morphology and respiratory activity of Phanerochaete chrysosporium biofilms. Bioresour. Technol. 2016, 210, 138-145. [CrossRef]

68. Espinosa-Ortiz, E.J.; Gonzalez-Gil, G.; Saikaly, P.E.; van Hullebusch, E.D.; Lens, P.N. Effects of selenium oxyanions on the white-rot fungus Phanerochaete chrysosporium. Appl. Microbiol. Biotechnol. 2015, 99, 2405-2418. [CrossRef]

69. Gharieb, M.M.; Gadd, G.M. The kinetics of ${ }^{75}$ [Se]-selenite uptake by Saccharomyces cerevisiae and the vacuolization response to high concentrations. Mycol. Res. 2004, 108, 1415-1422. [CrossRef]

70. Verma, A.; Gautam, S.P.; Bansal, K.K.; Prabhakar, N.; Rosenholm, J.M. Green Nanotechnology: Advancement in Phytoformulation Research. Medicines 2019, 6. [CrossRef]

71. Zonaro, E.; Lampis, S.; Turner, R.J.; Qazi, S.J.; Vallini, G. Biogenic selenium and tellurium nanoparticles synthesized by environmental microbial isolates efficaciously inhibit bacterial planktonic cultures and biofilms. Front. Microbiol. 2015, 6, 584. [CrossRef] [PubMed] 
72. Pearce, C.I.; Pattrick, R.A.; Law, N.; Charnock, J.M.; Coker, V.S.; Fellowes, J.W.; Oremland, R.S.; Lloyd, J.R. Investigating different mechanisms for biogenic selenite transformations: Geobacter sulfurreducens, Shewanella oneidensis and Veillonella atypica. Environ. Technol. 2009, 30, 1313-1326. [CrossRef]

73. Pasula, R.R.; Lim, S. Engineering nanoparticle synthesis using microbial factories. Eng. Biol. 2017, 1, 12-17. [CrossRef]

74. Ruiz Fresneda, M.A.; Delgado Martín, J.; Gómez Bolívar, J.; Fernández Cantos, M.V.; Bosch-Estévez, G.; Martínez Moreno, M.F.; Merroun, M.L. Green synthesis and biotransformation of amorphous Se nanospheres to trigonal 1D Se nanostructures: Impact on Se mobility within the concept of radioactive waste disposal. Environ. Sci. Nano 2018, 5, 2103-2116. [CrossRef]

75. Xia, X.; Wu, S.; Li, N.; Wang, D.; Zheng, S.; Wang, G. Novel bacterial selenite reductase CsrF responsible for Se(IV) and Cr(VI) reduction that produces nanoparticles in Alishewanella sp. WH16-1. J. Hazard. Mater. 2018, 342, 499-509. [CrossRef]

76. Rajasree, R.S.R.; Gayathri, S. Extracellular biosynthesis of Selenium nanoparticles using some species of Lactobacillus. Indian J. Geo-Marine Sci. 2015, 43, 766-775.

77. Dahoumane, S.A.; Djediat, C.; Yéprémian, C.; Couté, A.; Fiévet, F.; Coradin, T.; Brayner, R. Species selection for the design of gold nanobioreactor by photosynthetic organisms. J. Nanopart. Res. 2012, 14. [CrossRef]

78. Dahoumane, S.A.; Mechouet, M.; Alvarez, F.J.; Agathos, S.N.; Jeffryes, C. Microalgae: An outstanding tool in nanotechnology. Bionatura 2016, 1. [CrossRef]

79. Dahoumane, S.A.; Wijesekera, K.; Filipe, C.D.; Brennan, J.D. Stoichiometrically controlled production of bimetallic Gold-Silver alloy colloids using micro-alga cultures. J. Colloid Interface Sci. 2014, 416, 67-72. [CrossRef] [PubMed]

80. Alqadi, M.K.; Abo Noqtah, O.A.; Alzoubi, F.Y.; Alzouby, J.; Aljarrah, K. pH effect on the aggregation of silver nanoparticles synthesized by chemical reduction. Mater. Sci. Pol. 2014, 32, 107-111. [CrossRef]

81. Castro, L.; Blázquez, M.L.; González, F.; Muñoz, J.A.; Ballester, A. Extracellular biosynthesis of gold nanoparticles using sugar beet pulp. Chem. Eng. J. 2010, 164, 92-97. [CrossRef]

82. Wu, S.; Sun, K.; Wang, X.; Wang, D.; Wan, X.; Zhang, J. Protonation of epigallocatechin-3-gallate (EGCG) results in massive aggregation and reduced oral bioavailability of EGCG-dispersed selenium nanoparticles. J. Agric. Food. Chem. 2013, 61, 7268-7275. [CrossRef] [PubMed]

83. Akcay, F.A.; Avci, A. Effects of process conditions and yeast extract on the synthesis of selenium nanoparticles by a novel indigenous isolate Bacillus sp. EKT1 and characterization of nanoparticles. Arch. Microbiol. 2020, 202, 2233-2243. [CrossRef]

84. Kuroda, M.; Notaguchi, E.; Sato, A.; Yoshioka, M.; Hasegawa, A.; Kagami, T.; Narita, T.; Yamashita, M.; Sei, K.; Soda, S.; et al. Characterization of Pseudomonas stutzeri NT-I capable of removing soluble selenium from the aqueous phase under aerobic conditions. J. Biosci. Bioeng. 2011, 112, 259-264. [CrossRef] [PubMed]

85. Ge, J.P.; Xu, S.; Liu, L.P.; Li, Y.D. A positive-microemulsion method for preparing nearly uniform $\mathrm{Ag}_{2}$ Se nanoparticles at low temperature. Chem. Eur. J. 2006, 12, 3672-3677. [CrossRef]

86. Mollania, N.; Tayebee, R.; Narenji-Sani, F. An environmentally benign method for the biosynthesis of stable selenium nanoparticles. Res. Chem. Intermed. 2015, 42, 4253-4271. [CrossRef]

87. Ashour, A.H.; El-Batal, A.I.; Maksoud, M.I.A.A.; El-Sayyad, G.S.; Labib, S.; Abdeltwab, E.; El-Okr, M.M. Antimicrobial activity of metal-substituted cobalt ferrite nanoparticles synthesized by sol-gel technique. Particuology 2018, 40, 141-151. [CrossRef]

88. Wong, C.W.; Chan, Y.S.; Jeevanandam, J.; Pal, K.; Bechelany, M.; Abd Elkodous, M.; El-Sayyad, G.S. Response Surface Methodology Optimization of Mono-dispersed MgO Nanoparticles Fabricated by Ultrasonic-Assisted Sol-Gel Method for Outstanding Antimicrobial and Antibiofilm Activities. J. Clust. Sci. 2020, 31, 367-389. [CrossRef]

89. Baer, D.R. Surface Characterization of Nanoparticles: Critical needs and significant challenges. J. Surf. Anal. 2011, 17, 163-169. [CrossRef]

90. Sadtler, B.; Burgos, S.P.; Batara, N.A.; Beardslee, J.A.; Atwater, H.A.; Lewis, N.S. Phototropic growth control of nanoscale pattern formation in photoelectrodeposited Se-Te films. Proc. Natl. Acad. Sci. USA 2013, 110, 19707-19712. [CrossRef]

91. Vijayanandan, A.S.; Balakrishnan, R.M. Impact of precursor concentration on biological synthesis of cobalt oxide nanoparticles. Data Brief 2018, 19, 1941-1947. [CrossRef] [PubMed]

92. Sharifi Dehsari, H.; Halda Ribeiro, A.; Ersöz, B.; Tremel, W.; Jakob, G.; Asadi, K. Effect of precursor concentration on size evolution of iron oxide nanoparticles. CrystEngComm 2017, 19, 6694-6702. [CrossRef]

93. Moloto, N.; Revaprasadu, N.; Musetha, P.L.; Moloto, M.J. The effect of precursor concentration, temperature and capping group on the morphology of CdS nanoparticles. J. Nanosci. Nanotechnol. 2009, 9, 4760-4766. [CrossRef] [PubMed]

94. Dahoumane, S.A.; Djediat, C.; Yepremian, C.; Coute, A.; Fievet, F.; Coradin, T.; Brayner, R. Recycling and adaptation of Klebsormidium flaccidum microalgae for the sustained production of gold nanoparticles. Biotechnol. Bioeng. 2012, 109, $284-288$. [CrossRef] [PubMed]

95. Rahman, A.; Kumar, S.; Bafana, A.; Dahoumane, S.A.; Jeffryes, C. Individual and Combined Effects of Extracellular Polymeric Substances and Whole Cell Components of Chlamydomonas reinhardtii on Silver Nanoparticle Synthesis and Stability. Molecules 2019, 24. [CrossRef]

96. Chaudhary, S.; Mehta, S.K. Selenium nanomaterials: Applications in electronics, catalysis and sensors. J. Nanosci. Nanotechnol. 2014, 14, 1658-1674. [CrossRef]

97. Wang, X.; Liu, G.; Zhou, J.; Wang, J.; Jin, R.; Lv, H. Quinone-mediated reduction of selenite and tellurite by Escherichia coli. Bioresour. Technol. 2011, 102, 3268-3271. [CrossRef] 
98. Presentato, A.; Piacenza, E.; Darbandi, A.; Anikovskiy, M.; Cappelletti, M.; Zannoni, D.; Turner, R.J. Assembly, growth and conductive properties of tellurium nanorods produced by Rhodococcus aetherivorans BCP1. Sci. Rep. 2018, 8, 3923. [CrossRef]

99. Presentato, A.; Piacenza, E.; Anikovskiy, M.; Cappelletti, M.; Zannoni, D.; Turner, R.J. Biosynthesis of selenium-nanoparticles and -nanorods as a product of selenite bioconversion by the aerobic bacterium Rhodococcus aetherivorans BCP1. New Biotechnol. 2018, 41, 1-8. [CrossRef]

100. Prange, A.; Birzele, B.; Hormes, J.; Modrow, H. Investigation of different human pathogenic and food contaminating bacteria and moulds grown on selenite/selenate and tellurite/tellurate by X-ray absorption spectroscopy. Food Control. 2005, 16, 723-728. [CrossRef]

101. Wang, T.; Yang, L.; Zhang, B.; Liu, J. Extracellular biosynthesis and transformation of selenium nanoparticles and application in $\mathrm{H}_{2} \mathrm{O}_{2}$ biosensor. Colloid Surf. B Biointerface. 2010, 80, 94-102. [CrossRef] [PubMed]

102. Menon, S.; Shanmugam, V. Cytotoxicity Analysis of Biosynthesized Selenium Nanoparticles Towards A549 Lung Cancer Cell Line. J. Inorg. Organometal. Polym. Mater. 2019, 30, 1852-1864. [CrossRef]

103. Rajkumar, K.; Mvs, S.; Koganti, S.; Burgula, S. Selenium Nanoparticles Synthesized Using Pseudomonas stutzeri (MH191156) Show Antiproliferative and Anti-angiogenic Activity Against Cervical Cancer Cells. Int. J. Nanomed. 2020, 15, 4523-4540. [CrossRef] [PubMed]

104. Sayes, C.M.; Warheit, D.B. Characterization of nanomaterials for toxicity assessment. Adv. Rev. 2009, 1, 960-970. [CrossRef] [PubMed]

105. Warheit, D.B. Nanoparticles. Mater. Today 2004, 7, 32-35. [CrossRef]

106. Warheit, D.B.; Sayes, C.M.; Reed, K.L.; Swain, K.A. Health effects related to nanoparticle exposures: Environmental, health and safety considerations for assessing hazards and risks. Pharmacol. Ther. 2008, 120, 35-42. [CrossRef]

107. Powers, K.W.; Palazuelos, M.; Moudgil, B.M.; Roberts, S.M. Characterization of the size, shape, and state of dispersion of nanoparticles for toxicological studies. Nanotoxicology 2009, 1, 42-51. [CrossRef]

108. Kapur, M.; Soni, K.; Kohli, K. Green Synthesis of Selenium Nanoparticles from Broccoli, Characterization, Application and Toxicity. Adv. Tech. Biol. Med. 2017, 5. [CrossRef]

109. Estevam, E.C.; Griffin, S.; Nasim, M.J.; Denezhkin, P.; Schneider, R.; Lilischkis, R.; Dominguez-Alvarez, E.; Witek, K.; Latacz, G.; Keck, C.; et al. Natural selenium particles from Staphylococcus carnosus: Hazards or particles with particular promise? J. Hazard. Mater. 2017, 324, 22-30. [CrossRef] [PubMed]

110. Bajaj, M.; Schmidt, S.; Winter, J. Formation of Se (0) Nanoparticles by Duganella sp. and Agrobacterium sp. isolated from Se-laden soil of North-East Punjab, India. Microb. Cell Fact. 2012, 11, 64. [CrossRef] [PubMed]

111. Combs, G.F.J.; Garbisu, C.; Yee, B.C.; Yee, A.; Carlson, D.E.; Smith, N.R.; Magyarosy, A.C.; Leighton, T.; Buchanan, B.B. Bioavailability of Selenium Accumulated by Selenite-reducing Bacteria. Biol. Trace Elem. Res. 1996, 52, 209-225. [CrossRef]

112. Kenward, P.A.; Fowle, D.A.; Yee, N. Microbial Selenate Sorption and Reduction in Nutrient Limited Systems. Environ. Sci. Technol. 2006, 40, 3782-3786. [CrossRef] [PubMed]

113. Lampis, S.; Zonaro, E.; Bertolini, C.; Cecconi, D.; Monti, F.; Micaroni, M.; Turner, R.J.; Butler, C.S.; Vallini, G. Selenite biotransformation and detoxification by Stenotrophomonas maltophilia SeITE02: Novel clues on the route to bacterial biogenesis of selenium nanoparticles. J. Hazard. Mater. 2017, 324, 3-14. [CrossRef] [PubMed]

114. Cremonini, E.; Zonaro, E.; Donini, M.; Lampis, S.; Boaretti, M.; Dusi, S.; Melotti, P.; Lleo, M.M.; Vallini, G. Biogenic selenium nanoparticles: Characterization, antimicrobial activity and effects on human dendritic cells and fibroblasts. Microb. Biotechnol. 2016, 9, 758-771. [CrossRef] [PubMed]

115. Figueroa, M.; Fernandez, V.; Arenas-Salinas, M.; Ahumada, D.; Munoz-Villagran, C.; Cornejo, F.; Vargas, E.; Latorre, M.; Morales, E.; Vasquez, C.; et al. Synthesis and Antibacterial Activity of Metal(loid) Nanostructures by Environmental Multi-Metal(loid) Resistant Bacteria and Metal(loid)-Reducing Flavoproteins. Front. Microbiol. 2018, 9, 959. [CrossRef]

116. Tam, K.; Ho, C.T.; Lee, J.H.; Lai, M.; Chang, C.H.; Rheem, Y.; Chen, W.; Hur, H.G.; Myung, N.V. Growth mechanism of amorphous selenium nanoparticles synthesized by Shewanella sp. HN-41. Biosci. Biotechnol. Biochem. 2010, 74, 696-700. [CrossRef]

117. Shakibaie, M.; Khorramizadeh, M.R.; Faramarzi, M.A.; Sabzevari, O.; Shahverdi, A.R. Biosynthesis and recovery of selenium nanoparticles and the effects on matrix metalloproteinase-2 expression. Biotechnol. Appl. Biochem. 2010, 56, 7-15. [CrossRef] [PubMed]

118. Shakibaie, M.; Forootanfar, H.; Golkari, Y.; Mohammadi-Khorsand, T.; Shakibaie, M.R. Anti-biofilm activity of biogenic selenium nanoparticles and selenium dioxide against clinical isolates of Staphylococcus aureus, Pseudomonas aeruginosa, and Proteus mirabilis. J. Trace Elem. Med. Biol. 2015, 29, 235-241. [CrossRef] [PubMed]

119. Beheshti, N.; Soflaei, S.; Shakibaie, M.; Yazdi, M.H.; Ghaffarifar, F.; Dalimi, A.; Shahverdi, A.R. Efficacy of biogenic selenium nanoparticles against Leishmania major: In vitro and in vivo studies. J. Trace Elem. Med. Biol. 2013, 27, 203-207. [CrossRef] [PubMed]

120. Forootanfar, H.; Adeli-Sardou, M.; Nikkhoo, M.; Mehrabani, M.; Amir-Heidari, B.; Shahverdi, A.R.; Shakibaie, M. Antioxidant and cytotoxic effect of biologically synthesized selenium nanoparticles in comparison to selenium dioxide. J. Trace Elem. Med. Biol. 2014, 28, 75-79. [CrossRef]

121. Fernandez-Llamosas, H.; Castro, L.; Blazquez, M.L.; Diaz, E.; Carmona, M. Biosynthesis of selenium nanoparticles by Azoarcus sp. CIB. Microb. Cell Fact. 2016, 15, 109. [CrossRef] [PubMed]

122. Khoei, N.S.; Lampis, S.; Zonaro, E.; Yrjala, K.; Bernardi, P.; Vallini, G. Insights into selenite reduction and biogenesis of elemental selenium nanoparticles by two environmental isolates of Burkholderia fungorum. New Biotechnol. 2017, 34, 1-11. [CrossRef] [PubMed] 
123. Tan, Y.; Wang, Y.; Wang, Y.; Xu, D.; Huang, Y.; Wang, D.; Wang, G.; Rensing, C.; Zheng, S. Novel mechanisms of selenate and selenite reduction in the obligate aerobic bacterium Comamonas testosteroni S44. J. Hazard. Mater. 2018, 359, 129-138. [CrossRef] [PubMed]

124. Kamnev, A.A.; Mamchenkova, P.V.; Dyatlova, Y.A.; Tugarova, A.V. FTIR spectroscopic studies of selenite reduction by cells of the rhizobacterium Azospirillum brasilense Sp7 and the formation of selenium nanoparticles. J. Mol. Struct. 2017, 1140, 106-112. [CrossRef]

125. Vogel, M.; Fischer, S.; Maffert, A.; Hubner, R.; Scheinost, A.C.; Franzen, C.; Steudtner, R. Biotransformation and detoxification of selenite by microbial biogenesis of selenium-sulfur nanoparticles. J. Hazard. Mater. 2018, 344, 749-757. [CrossRef]

126. Kora, A.J.; Rastogi, L. Biomimetic synthesis of selenium nanoparticles by Pseudomonas aeruginosa ATCC 27853: An approach for conversion of selenite. J. Environ. Manag. 2016, 181, 231-236. [CrossRef]

127. Pouri, S.; Motamedi, H.; Honary, S.; Kazeminezhad, I. Biological Synthesis of Selenium Nanoparticles and Evaluation of their Bioavailability. Braz. Arch. Biol. Techn. 2018, 60. [CrossRef]

128. Srivastava, N.; Mukhopadhyay, M. Biosynthesis and structural characterization of selenium nanoparticles mediated by Zooglea ramigera. Powder Technol. 2013, 244, 26-29. [CrossRef]

129. Subedi, G.; Taylor, J.; Hatam, I.; Baldwin, S.A. Simultaneous selenate reduction and denitrification by a consortium of enriched mine site bacteria. Chemosphere 2017, 183, 536-545. [CrossRef]

130. Wadhwani, S.A.; Shedbalkar, U.U.; Singh, R.; Chopade, B.A. Biosynthesis of gold and selenium nanoparticles by purified protein from Acinetobacter sp. SW 30. Enzyme Microb. Technol. 2018, 111, 81-86. [CrossRef]

131. Ramya, S.; Shanmugasundaram, T.; Balagurunathan, R. Biomedical potential of actinobacterially synthesized selenium nanoparticles with special reference to anti-biofilm, anti-oxidant, wound healing, cytotoxic and anti-viral activities. J. Trace Elem. Med. Biol. 2015, 32, 30-39. [CrossRef] [PubMed]

132. Ameri, A.; Shakibaie, M.; Ameri, A.; Faramarzi, M.A.; Amir-Heidari, B.; Forootanfar, H. Photocatalytic decolorization of bromothymol blue using biogenic selenium nanoparticles synthesized by terrestrial actinomycete Streptomyces griseobrunneus strain FSHH12. Desalin. Water Treat. 2015, 57, 21552-21563. [CrossRef]

133. Fernandez-Llamosas, H.; Castro, L.; Blazquez, M.L.; Diaz, E.; Carmona, M. Speeding up bioproduction of selenium nanoparticles by using Vibrio natriegens as microbial factory. Sci. Rep. 2017, 7, 16046. [CrossRef] [PubMed]

134. Xu, C.; Guo, Y.; Qiao, L.; Ma, L.; Cheng, Y.; Roman, A. Biogenic Synthesis of Novel Functionalized Selenium Nanoparticles by Lactobacillus casei ATCC 393 and Its Protective Effects on Intestinal Barrier Dysfunction Caused by Enterotoxigenic Escherichia coli K88. Front. Microbiol. 2018, 9, 1129. [CrossRef] [PubMed]

135. Shaaban, M.; El-Mahdy, A.M. Biosynthesis of Ag, Se, and $\mathrm{ZnO}$ nanoparticles with antimicrobial activities against resistant pathogens using waste isolate Streptomyces enissocaesilis. IET Nanobiotechnol. 2018, 12, 741-747. [CrossRef] [PubMed]

136. Ramya, S.; Shanmugasundaram, T.; Balagurunathan, R. Actinobacterial enzyme mediated synthesis of selenium nanoparticles for antibacterial, mosquito larvicidal and anthelminthic applications. Particul. Sci. Technol. 2019, 38, 63-72. [CrossRef]

137. San Keskin, N.O.; Akbal Vural, O.; Abaci, S. Biosynthesis of Noble Selenium Nanoparticles from Lysinibacillus sp. NOSK for Antimicrobial, Antibiofilm Activity, and Biocompatibility. Geomicrobiol. J. 2020, 37, 919-928. [CrossRef]

138. Srivastava, P.; Kowshik, M. Anti-neoplastic selenium nanoparticles from Idiomarina sp. PR58-8. Enzyme Microb. Technol. 2016, 95, 192-200. [CrossRef]

139. Srivastava, N.; Mukhopadhyay, M. Green synthesis and structural characterization of selenium nanoparticles and assessment of their antimicrobial property. Bioprocess. Biosyst. Eng. 2015, 38, 1723-1730. [CrossRef]

140. Song, D.; Li, X.; Cheng, Y.; Xiao, X.; Lu, Z.; Wang, Y.; Wang, F. Aerobic biogenesis of selenium nanoparticles by Enterobacter cloacae Z0206 as a consequence of fumarate reductase mediated selenite reduction. Sci. Rep. 2017, 7. [CrossRef]

141. Li, D.B.; Cheng, Y.Y.; Wu, C.; Li, W.W.; Li, N.; Yang, Z.C.; Tong, Z.H.; Yu, H.Q. Selenite reduction by Shewanella oneidensis MR-1 is mediated by fumarate reductase in periplasm. Sci. Rep. 2014, 4. [CrossRef] [PubMed]

142. Hnain, A.; Brooks, J.; Lefebvre, D.D. The synthesis of elemental selenium particles by Synechococcus leopoliensis. Appl. Microbiol. Biotechnol. 2013, 97, 10511-10519. [CrossRef] [PubMed]

143. Zheng, S.; Su, J.; Wang, L.; Yao, R.; Wang, D.; Deng, Y.; Wang, R.; Wang, G.; Rensing, C. Selenite reduction by the obligate aerobic bacterium Comamonas testosteroni S44 isolated from a metal-contaminated soil. BMC Microbiol. 2014, 14, 204. [CrossRef] [PubMed]

144. Tugarova, A.V.; Mamchenkova, P.V.; Khanadeev, V.A.; Kamnev, A.A. Selenite reduction by the rhizobacterium Azospirillum brasilense, synthesis of extracellular selenium nanoparticles and their characterisation. N. Biotechnol. 2020, 58, 17-24. [CrossRef] [PubMed]

145. Kora, A.J. Bacillus cereus, selenite-reducing bacterium from contaminated lake of an industrial area: A renewable nanofactory for the synthesis of selenium nanoparticles. Bioresour. Bioprocess. 2018, 5. [CrossRef]

146. Eszenyi, P.; Sztrik, A.; Babka, B.; Prokisch, J. Elemental, Nano-Sized (100-500 nm) Selenium Production by Probiotic Lactic Acid Bacteria. Int. J. Biosci. Biochem. Bioinform. 2011, 1, 148-152. [CrossRef]

147. Shakibaie, M.; Shahverdi, A.R.; Faramarzi, M.A.; Hassanzadeh, G.R.; Rahimi, H.R.; Sabzevari, O. Acute and subacute toxicity of novel biogenic selenium nanoparticles in mice. Pharm. Biol. 2013, 51, 58-63. [CrossRef]

148. Xu, C.; Qiao, L.; Guo, Y.; Ma, L.; Cheng, Y. Preparation, characteristics and antioxidant activity of polysaccharides and proteinscapped selenium nanoparticles synthesized by Lactobacillus casei ATCC 393. Carbohydr. Polym. 2018, 195, 576-585. [CrossRef]

149. Wadgaonkar, S.L.; Mal, J.; Nancharaiah, Y.V.; Maheshwari, N.O.; Esposito, G.; Lens, P.N.L. Formation of Se(0), Te(0), and $\mathrm{Se}(0)-\mathrm{Te}(0)$ nanostructures during simultaneous bioreduction of selenite and tellurite in a UASB reactor. Appl. Microbiol. Biotechnol. 2018, 102, 2899-2911. [CrossRef] 
150. Staicu, L.C.; van Hullebusch, E.D.; Oturan, M.A.; Ackerson, C.J.; Lens, P.N. Removal of colloidal biogenic selenium from wastewater. Chemosphere 2015, 125, 130-138. [CrossRef]

151. Dessi, P.; Jain, R.; Singh, S.; Seder-Colomina, M.; van Hullebusch, E.D.; Rene, E.R.; Ahammad, S.Z.; Carucci, A.; Lens, P.N.L. Effect of temperature on selenium removal from wastewater by UASB reactors. Water Res. 2016, 94, 146-154. [CrossRef] [PubMed]

152. Liu, W.; Golshan, N.H.; Deng, X.; Hickey, D.J.; Zeimer, K.; Li, H.; Webster, T.J. Selenium nanoparticles incorporated into titania nanotubes inhibit bacterial growth and macrophage proliferation. Nanoscale 2016, 8, 15783-15794. [CrossRef] [PubMed]

153. Eswayah, A.S.; Smith, T.J.; Gardiner, P.H. Microbial Transformations of Selenium Species of Relevance to Bioremediation. Appl. Environ. Microbiol. 2016, 82, 4848-4859. [CrossRef] [PubMed]

154. Shoeibi, S.; Mozdziak, P.; Golkar-Narenji, A. Biogenesis of Selenium Nanoparticles Using Green Chemistry. Top. Curr. Chem. 2017, 375, 88. [CrossRef] [PubMed]

155. Nancharaiah, Y.V.; Lens, P.N. Ecology and biotechnology of selenium-respiring bacteria. Microbiol. Mol. Biol. Rev. 2015, 79, 61-80. [CrossRef]

156. Tan, Y.; Yao, R.; Wang, R.; Wang, D.; Wang, G.; Zheng, S. Reduction of selenite to Se(0) nanoparticles by filamentous bacterium Streptomyces sp. ES2-5 isolated from a selenium mining soil. Microb. Cell Fact. 2016, 15, 157. [CrossRef]

157. Tomei, F.A.; Barton, L.L.; Lemanski, C.L.; Zocco, T.G.; Fink, N.H.; Sillerud, L.O. Transformation of selenate and selenite to elemental selenium by Desulfovibrio desulfuricans. J. Indus. Microbiol. 1995, 14, 329-336. [CrossRef]

158. Losi, M.E.; Frankenberger, W.T., Jr. Reduction of Selenium Oxyanions by Enterobacter cloacae SLD1a-1: Isolation and Growth of the Bacterium and Its Expulsion of Selenium Particles. Appl. Environ. Microbiol. 1997, 63, 3079-3084. [CrossRef]

159. Kessi, J.; Ramuz, M.; Wehrli, E.; Spycher, M.; Bachofen, R. Reduction of Selenite and Detoxification of Elemental Selenium by the Phototrophic Bacterium Rhodospirillum rubrum. Appl. Environ. Microbiol. 1999, 65, 4734-4740. [CrossRef]

160. Tan, L.C.; Nancharaiah, Y.V.; van Hullebusch, E.D.; Lens, P.N.L. Selenium: Environmental significance, pollution, and biological treatment technologies. Biotechnol. Adv. 2016, 34, 886-907. [CrossRef]

161. Kessi, J.; Hanselmann, K.W. Similarities between the abiotic reduction of selenite with glutathione and the dissimilatory reaction mediated by Rhodospirillum rubrum and Escherichia coli. J. Biol. Chem. 2004, 279, 50662-50669. [CrossRef] [PubMed]

162. Hunter, W.J. Pseudomonas seleniipraecipitans proteins potentially involved in selenite reduction. Curr. Microbiol. 2014, 69, 69-74. [CrossRef] [PubMed]

163. Chung, S.; Zhou, R.; Webster, T.J. Green Synthesized BSA-Coated Selenium Nanoparticles Inhibit Bacterial Growth While Promoting Mammalian Cell Growth. Int. J. Nanomed. 2020, 15, 115-124. [CrossRef] [PubMed]

164. Zhao, G.; Wu, X.; Chen, P.; Zhang, L.; Yang, C.S.; Zhang, J. Selenium nanoparticles are more efficient than sodium selenite in producing reactive oxygen species and hyper-accumulation of selenium nanoparticles in cancer cells generates potent therapeutic effects. Free Radic. Biol. Med. 2018, 126, 55-66. [CrossRef] [PubMed]

165. Krafft, T.; Bowen, A.; Theis, F.; Macy, J.M. Cloning and Sequencing of the Genes Encoding the Periplasmic-Cytochrome BContaining Selenate Reductase of Thauera selenafis. DNA Seq. 2000, 10, 365-377. [CrossRef] [PubMed]

166. Hunter, W.J. A Rhizobium selenitireducens protein showing selenite reductase activity. Curr. Microbiol. 2014, 68, 311-316. [CrossRef]

167. Kuroda, M.; Yamashita, M.; Miwa, E.; Imao, K.; Fujimoto, N.; Ono, H.; Nagano, K.; Sei, K.; Ike, M. Molecular cloning and characterization of the srdBCA operon, encoding the respiratory selenate reductase complex, from the selenate-reducing bacterium Bacillus selenatarsenatis SF-1. J. Bacteriol. 2011, 193, 2141-2148. [CrossRef]

168. Afkar, E.; Lisak, J.; Saltikov, C.; Basu, P.; Oremland, R.S.; Stolz, J.F. The respiratory arsenate reductase from Bacillus selenitireducens strain MLS10. FEMS Microbiol. Lett. 2003, 226, 107-112. [CrossRef]

169. Harrison, G.; Curie, C.; Laishley, E.J. Purification and characterization of an inducible dissimilatory type sulfite reductase from Clostridium pasteurianum. Arch. Microbiol. 1984, 138, 72-78. [CrossRef]

170. Yanke, L.J.; Bryant, R.D.; Laishley, E.J. Hydrogenase I of Clostridium pasteurianum functions as a novel selenite reductase. Anaerobe 1995, 1, 61-67. [CrossRef]

171. DeMoll-Decker, H.; Macy, J.M. The periplasmic nitrite reductase of Thauera selenatis may catalyze the reduction of selenite to elemental selenium. Arch. Microbiol. 1993, 160, 241-247.

172. Ridley, H.; Watts, C.A.; Richardson, D.J.; Butler, C.S. Resolution of distinct membrane-bound enzymes from Enterobacter cloacae SLD1a-1 that are responsible for selective reduction of nitrate and selenate oxyanions. Appl. Environ. Microbiol. 2006, 72, 5173-5180. [CrossRef] [PubMed]

173. Kessi, J. Enzymic systems proposed to be involved in the dissimilatory reduction of selenite in the purple non-sulfur bacteria Rhodospirillum rubrum and Rhodobacter capsulatus. Microbiology 2006, 152, 731-743. [CrossRef] [PubMed]

174. Sonkusre, P.; Nanduri, R.; Gupta, P.; Singh Cameotra, S. Improved Extraction of Intracellular Biogenic Selenium Nanoparticles and their Specificity for Cancer Chemoprevention. Nanomed. Nanotechnol. 2014, 5. [CrossRef]

175. Lenz, M.; Kolvenbach, B.; Gygax, B.; Moes, S.; Corvini, P.F. Shedding light on selenium biomineralization: Proteins associated with bionanominerals. Appl. Environ. Microbiol. 2011, 77, 4676-4680. [CrossRef]

176. Lynch, I.; Dawson, K.A. Protein-nanoparticle interactions. Nano Today 2008, 3, 40-47. [CrossRef]

177. Xue, L.; Greisler, H.P. Biomaterials in the development and future of vascular grafts. J. Vasc. Surg. 2003, 37, 472-480. [CrossRef]

178. Dhillon, G.S.; Brar, S.K.; Kaur, S.; Verma, M. Green approach for nanoparticle biosynthesis by fungi: Current trends and applications. Crit. Rev. Biotechnol. 2012, 32, 49-73. [CrossRef] 
179. Boroumand Moghaddam, A.; Namvar, F.; Moniri, M.; Md Tahir, P.; Azizi, S.; Mohamad, R. Nanoparticles Biosynthesized by Fungi and Yeast: A Review of Their Preparation, Properties, and Medical Applications. Molecules 2015, 20, 16540-16565. [CrossRef]

180. Sarkar, J.; Dey, P.; Saha, S.; Acharya, K. Mycosynthesis of selenium nanoparticles. Micro Nano Lett. 2011, 6, 599. [CrossRef]

181. Joshi, S.M.; De Britto, S.; Jogaiah, S.; Ito, S.I. Mycogenic Selenium Nanoparticles as Potential New Generation Broad Spectrum Antifungal Molecules. Biomolecules 2019, 9. [CrossRef] [PubMed]

182. Diko, C.S.; Zhang, H.; Lian, S.; Fan, S.; Li, Z.; Qu, Y. Optimal synthesis conditions and characterization of selenium nanoparticles in Trichoderma sp. WL-Go culture broth. Mater. Chem. Phys. 2020, 246, 122583. [CrossRef]

183. Liang, T.; Qiu, X.; Ye, X.; Liu, Y.; Li, Z.; Tian, B.; Yan, D. Biosynthesis of selenium nanoparticles and their effect on changes in urinary nanocrystallites in calcium oxalate stone formation. 3 Biotech. 2020, 10, 23. [CrossRef] [PubMed]

184. Mosallam, F.M.; El-Sayyad, G.S.; Fathy, R.M.; El-Batal, A.I. Biomolecules-mediated synthesis of selenium nanoparticles using Aspergillus oryzae fermented Lupin extract and gamma radiation for hindering the growth of some multidrug-resistant bacteria and pathogenic fungi. Microb. Pathog. 2018, 122, 108-116. [CrossRef] [PubMed]

185. El-Batal, A.I.; Mosallam, F.M.; Ghorab, M.M.; Hanora, A.; Gobara, M.; Baraka, A.; Elsayed, M.A.; Pal, K.; Fathy, R.M.; Abd Elkodous, M.; et al. Factorial design-optimized and gamma irradiation-assisted fabrication of selenium nanoparticles by chitosan and Pleurotus ostreatus fermented fenugreek for a vigorous in vitro effect against carcinoma cells. Int. J. Biol. Macromol. 2020, 156, 1584-1599. [CrossRef] [PubMed]

186. El-Sayyad, G.S.; El-Bastawisy, H.S.; Gobara, M.; El-Batal, A.I. Gentamicin-Assisted Mycogenic Selenium Nanoparticles Synthesized Under Gamma Irradiation for Robust Reluctance of Resistant Urinary Tract Infection-Causing Pathogens. Biol. Trace Elem. Res. 2020, 195, 323-342. [CrossRef]

187. Gao, X.; Li, X.; Mu, J.; Ho, C.T.; Su, J.; Zhang, Y.; Lin, X.; Chen, Z.; Li, B.; Xie, Y. Preparation, physicochemical characterization, and anti-proliferation of selenium nanoparticles stabilized by Polyporus umbellatus polysaccharide. Int. J. Biol. Macromol. 2020, 152, 605-615. [CrossRef]

188. Jin, Y.; Cai, L.; Yang, Q.; Luo, Z.; Liang, L.; Liang, Y.; Wu, B.; Ding, L.; Zhang, D.; Xu, X.; et al. Anti-leukemia activities of selenium nanoparticles embedded in nanotube consisted of triple-helix $\beta$-D-glucan. Carbohydr. Polym. 2020, 240, 116329. [CrossRef]

189. Liao, W.; Yu, Z.; Lin, Z.; Lei, Z.; Ning, Z.; Regenstein, J.M.; Yang, J.; Ren, J. Biofunctionalization of Selenium Nanoparticle with Dictyophora Indusiata Polysaccharide and Its Antiproliferative Activity through Death-Receptor and Mitochondria-Mediated Apoptotic Pathways. Sci. Rep. 2015, 5, 18629. [CrossRef]

190. Liu, Y.; Zeng, S.; Liu, Y.; Wu, W.; Shen, Y.; Zhang, L.; Li, C.; Chen, H.; Liu, A.; Shen, L.; et al. Synthesis and antidiabetic activity of selenium nanoparticles in the presence of polysaccharides from Catathelasma ventricosum. Int. J. Biol. Macromol. 2018, 114, 632-639. [CrossRef]

191. Rosenfeld, C.E.; Kenyon, J.A.; James, B.R.; Santelli, C.M. Selenium (IV,VI) reduction and tolerance by fungi in an oxic environment. Geobiology 2017, 15, 441-452. [CrossRef] [PubMed]

192. Vetchinkina, E.; Loshchinina, E.; Kupryashina, M.; Burov, A.; Pylaev, T.; Nikitina, V. Green synthesis of nanoparticles with extracellular and intracellular extracts of basidiomycetes. Peer] 2018, 6, e5237. [CrossRef] [PubMed]

193. Vetchinkina, E.; Loshchinina, E.; Kursky, V.; Nikitina, V. Reduction of organic and inorganic selenium compounds by the edible medicinal basidiomycete Lentinula edodes and the accumulation of elemental selenium nanoparticles in its mycelium. J. Microbiol. 2013, 51, 829-835. [CrossRef] [PubMed]

194. Vetchinkina, E.; Loshchinina, E.; Kupryashina, M.; Burov, A.; Nikitina, V. Shape and Size Diversity of Gold, Silver, Selenium, and Silica Nanoparticles Prepared by Green Synthesis Using Fungi and Bacteria. Indus. Eng. Chem. Res. 2019, 58, 17207-17218. [CrossRef]

195. Xiao, Y.; Huang, Q.; Zheng, Z.; Guan, H.; Liu, S. Construction of a Cordyceps sinensis exopolysaccharide-conjugated selenium nanoparticles and enhancement of their antioxidant activities. Int. J. Biol. Macromol. 2017, 99, 483-491. [CrossRef] [PubMed]

196. Zhang, H.; Zhou, H.; Bai, J.; Li, Y.; Yang, J.; Ma, Q.; Qu, Y. Biosynthesis of selenium nanoparticles mediated by fungus Mariannaea sp. HJ and their characterization. Colloid Surf. A Physicochem. Eng. Aspect 2019, 571, 9-16. [CrossRef]

197. Srivastava, N.; Mukhopadhyay, M. Biosynthesis and Structural Characterization of Selenium Nanoparticles Using Gliocladium roseum. J. Cluster Sci. 2015, 26, 1473-1482. [CrossRef]

198. Gharieb, M.M.; Wilkinson, S.C.; Gadd, G.M. Reduction of selenium oxyanions by unicellular, polymorphic and filamentous fungi: Cellular location of reduced selenium and implications for tolerance. J. Indud. Microbiol. 1995, 14, 300-311. [CrossRef]

199. Das, S.K.; Dickinson, C.; Lafir, F.; Brougham, D.F.; Marsili, E. Synthesis, characterization and catalytic activity of gold nanoparticles biosynthesized with Rhizopus oryzae protein extract. Green Chem. 2012, 14, 1322-1334. [CrossRef]

200. Sarkar, J.; Acharya, K. Alternaria alternata culture filtrate mediated bioreduction of chloroplatinate to platinum nanoparticles. Inorg. Nano Metal. Chem. 2017, 47, 365-369. [CrossRef]

201. Sathishkumar, Y.; Devarayan, K.; Ki, C.; Rajagopal, K.; Soo Lee, Y. Shape-controlled extracellular synthesis of silver nanocubes by Mucor circinelloides. Mater. Lett. 2015, 159, 481-483. [CrossRef]

202. Herrero, E.; Wellinger, R.E. Yeast as a model system to study metabolic impact of selenium compounds. Microb. Cell 2015, 2, 139-149. [CrossRef] [PubMed]

203. Schrauzer, G.N. Selenium yeast: Composition, quality, analysis, and safety. Pure Appl. Chem. 2006, 78, 105-109. [CrossRef]

204. Rayman, M.P. The use of high-selenium yeast to raise selenium status: How does it measure up? Br. J. Nutr. 2004, 92, 557-573. [CrossRef] [PubMed] 
205. Jiménez-Lamana, J.; Abad-Álvaro, I.; Bierla, K.; Laborda, F.; Szpunar, J.; Lobinski, R. Detection and characterization of biogenic selenium nanoparticles in selenium-rich yeast by single particle ICPMS. J. Anal. Atom. Spectrom. 2018, 33, 452-460. [CrossRef]

206. Bartosiak, M.; Giersz, J.; Jankowski, K. Analytical monitoring of selenium nanoparticles green synthesis using photochemical vapor generation coupled with MIP-OES and UV-Vis spectrophotometry. Microchem. J. 2019, 145, 1169-1175. [CrossRef]

207. Lian, S.; Diko, C.S.; Yan, Y.; Li, Z.; Zhang, H.; Ma, Q.; Qu, Y. Characterization of biogenic selenium nanoparticles derived from cell-free extracts of a novel yeast Magnusiomyces ingens. 3 Biotech. 2019, 9. [CrossRef]

208. Faramarzi, S.; Anzabi, Y.; Jafarizadeh-Malmiri, H. Nanobiotechnology approach in intracellular selenium nanoparticle synthesis using Saccharomyces cerevisiae-fabrication and characterization. Arch. Microbiol. 2020, 202, 1203-1209. [CrossRef]

209. Asghari-Paskiabi, F.; Imani, M.; Rafii-Tabar, H.; Razzaghi-Abyaneh, M. Physicochemical properties, antifungal activity and cytotoxicity of selenium sulfide nanoparticles green synthesized by Saccharomyces cerevisiae. Biochem. Biophys. Res. Commun. 2019, 516, 1078-1084. [CrossRef]

210. Khakpour, H.; Younesi, H.; Mohammadhosseini, M. Two-stage biosorption of selenium from aqueous solution using dried biomass of the baker's yeast Saccharomyces cerevisiae. J. Environ. Chem. Eng. 2014, 2, 532-542. [CrossRef]

211. Zhang, L.; Li, D.; Gao, P. Expulsion of selenium/protein nanoparticles through vesicle-like structures by Saccharomyces cerevisiae under microaerophilic environment. World J. Microbiol. Biotechnol. 2012, 28, 3381-3386. [CrossRef] [PubMed]

212. Turner, R.J.; Borghese, R.; Zannoni, D. Microbial processing of tellurium as a tool in biotechnology. Biotechnol. Adv. 2012, 30, 954-963. [CrossRef] [PubMed]

213. Borghese, R.; Brucale, M.; Fortunato, G.; Lanzi, M.; Mezzi, A.; Valle, F.; Cavallini, M.; Zannoni, D. Extracellular production of tellurium nanoparticles by the photosynthetic bacterium Rhodobacter capsulatus. J. Hazard. Mater. 2016, 309, 202-209. [CrossRef] [PubMed]

214. Maltman, C.; Donald, L.J.; Yurkov, V. Tellurite and Tellurate Reduction by the Aerobic Anoxygenic Phototroph Erythromonas ursincola, Strain KR99 Is Carried out by a Novel Membrane Associated Enzyme. Microorganisms 2017, 5. [CrossRef] [PubMed]

215. Borghese, R.; Baccolini, C.; Francia, F.; Sabatino, P.; Turner, R.J.; Zannoni, D. Reduction of chalcogen oxyanions and generation of nanoprecipitates by the photosynthetic bacterium Rhodobacter capsulatus. J. Hazard. Mater. 2014, 269, 24-30. [CrossRef]

216. Presentato, A.; Piacenza, E.; Anikovskiy, M.; Cappelletti, M.; Zannoni, D.; Turner, R.J. Rhodococcus aetherivorans BCP1 as cell factory for the production of intracellular tellurium nanorods under aerobic conditions. Microb. Cell Fact. 2016, 15, 204. [CrossRef]

217. Wang, K.; Zhang, X.; Kislyakov, I.M.; Dong, N.; Zhang, S.; Wang, G.; Fan, J.; Zou, X.; Du, J.; Leng, Y.; et al. Bacterially synthesized tellurium nanostructures for broadband ultrafast nonlinear optical applications. Nat. Commun. 2019, 10, 3985. [CrossRef]

218. Pugin, B.; Cornejo, F.A.; Muñoz-Díaz, P.; Muñoz-Villagrán, C.M.; Vargas-Pérez, J.I.; Arenas, F.A.; Vásquez, C.C. Glutathione Reductase-Mediated Synthesis of Tellurium-Containing Nanostructures Exhibiting Antibacterial Properties. Appl. Environ. Microbiol. 2014, 80, 7061-7070. [CrossRef]

219. Nguyen, V.K.; Choi, W.; Ha, Y.; Gu, Y.; Lee, C.; Park, J.; Jang, G.; Shin, C.; Cho, S. Microbial tellurite reduction and production of elemental tellurium nanoparticles by novel bacteria isolated from wastewater. J. Indus. Eng. Chem. 2019, 78, 246-256. [CrossRef]

220. Castro, L.; Li, J.; González, F.; Muñoz, J.A.; Blázquez, M.L. Green synthesis of tellurium nanoparticles by tellurate and tellurite reduction using Aeromonas hydrophila under different aeration conditions. Hydrometallurgy 2020, 196, 105415. [CrossRef]

221. Zare, B.; Faramarzi, M.A.; Sepehrizadeh, Z.; Shakibaie, M.; Rezaie, S.; Shahverdi, A.R. Biosynthesis and recovery of rod-shaped tellurium nanoparticles and their bactericidal activities. Mater. Res. Bull. 2012, 47, 3719-3725. [CrossRef]

222. Ramos-Ruiz, A.; Field, J.A.; Wilkening, J.V.; Sierra-Alvarez, R. Recovery of Elemental Tellurium Nanoparticles by the Reduction of Tellurium Oxyanions in a Methanogenic Microbial Consortium. Environ. Sci. Technol. 2016, 50, 1492-1500. [CrossRef] [PubMed]

223. Ottosson, L.G.; Logg, K.; Ibstedt, S.; Sunnerhagen, P.; Kall, M.; Blomberg, A.; Warringer, J. Sulfate assimilation mediates tellurite reduction and toxicity in Saccharomyces cerevisiae. Eukaryot. Cell 2010, 9, 1635-1647. [CrossRef] [PubMed]

224. Yang, F.; Wong, K.H.; Yang, Y.; Li, X.; Jiang, J.; Zheng, W.; Wu, H.; Chen, T. Purification and in vitro antioxidant activities of tellurium-containing phycobiliproteins from tellurium-enriched Spirulina platensis. Drug Des. Devel. Ther. 2014, 8, 1789-1800. [CrossRef] [PubMed]

225. Arenas-Salinas, M.; Vargas-Perez, J.I.; Morales, W.; Pinto, C.; Munoz-Diaz, P.; Cornejo, F.A.; Pugin, B.; Sandoval, J.M.; DiazVasquez, W.A.; Munoz-Villagran, C.; et al. Flavoprotein-Mediated Tellurite Reduction: Structural Basis and Applications to the Synthesis of Tellurium-Containing Nanostructures. Front. Microbiol. 2016, 7, 1160. [CrossRef]

226. Klonowska, A.; Heulin, T.; Vermeglio, A. Selenite and tellurite reduction by Shewanella oneidensis. Appl. Environ. Microbiol. 2005, 71, 5607-5609. [CrossRef]

227. Alam, H.; Khatoon, N.; Raza, M.; Ghosh, P.C.; Sardar, M. Synthesis and Characterization of Nano Selenium Using Plant Biomolecules and Their Potential Applications. BioNanoScience 2019, 9, 96-104. [CrossRef]

228. Gunti, L.; Dass, R.S.; Kalagatur, N.K. Phytofabrication of Selenium Nanoparticles From Emblica officinalis Fruit Extract and Exploring Its Biopotential Applications: Antioxidant, Antimicrobial, and Biocompatibility. Front. Microbiol. 2019, 10, 931. [CrossRef]

229. Sowndarya, P.; Ramkumar, G.; Shivakumar, M.S. Green synthesis of selenium nanoparticles conjugated Clausena dentata plant leaf extract and their insecticidal potential against mosquito vectors. Artif. Cells Nanomed. Biotechnol. 2017, 45, 1490-1495. [CrossRef] [PubMed]

230. Marslin, G.; Siram, K.; Maqbool, Q.; Selvakesavan, R.K.; Kruszka, D.; Kachlicki, P.; Franklin, G. Secondary Metabolites in the Green Synthesis of Metallic Nanoparticles. Materials 2018, 11. [CrossRef] 
231. Mittal, A.K.; Kumar, S.; Banerjee, U.C. Quercetin and gallic acid mediated synthesis of bimetallic (silver and selenium) nanoparticles and their antitumor and antimicrobial potential. J. Colloid Interface Sci. 2014, 431, 194-199. [CrossRef]

232. Cobbett, C.S. Heavy Metal Detoxification in Plants: Phytochelatin Biosynthesis and Function. IUBMB Life 2001, 51, 183-188. [CrossRef]

233. Branco-Neves, S.; Soares, C.; de Sousa, A.; Martins, V.; Azenha, M.; Gerós, H.; Fidalgo, F. An efficient antioxidant system and heavy metal exclusion from leaves make Solanum cheesmaniae more tolerant to $\mathrm{Cu}$ than its cultivated counterpart. Food Energ. Secur. 2017, 6, 123-133. [CrossRef]

234. Schiavon, M.; Pilon-Smits, E.A. Selenium Biofortification and Phytoremediation Phytotechnologies: A Review. J. Environ. Qual. 2017, 46, 10-19. [CrossRef]

235. Vogrincic, M.; Cuderman, P.; Kreft, I.; Stibilj, V. Selenium and Its Species Distribution in Above-ground Plant Parts of Selenium Enriched Buckwheat (Fagopyrum esculentum Moench). Anal. Sci. 2009, 25, 1357-1363. [CrossRef]

236. Hu, T.; Li, H.; Li, J.; Zhao, G.; Wu, W.; Liu, L.; Wang, Q.; Guo, Y. Absorption and Bio-Transformation of Selenium Nanoparticles by Wheat Seedlings (Triticum aestivum L.). Front. Plant. Sci. 2018, 9, 597. [CrossRef]

237. Anu, K.; Devanesan, S.; Prasanth, R.; AlSalhi, M.S.; Ajithkumar, S.; Singaravelu, G. Biogenesis of selenium nanoparticles and their anti-leukemia activity. J. King Saud Univ. Sci. 2020, 32, 2520-2526. [CrossRef]

238. Fan, D.; Li, L.; Li, Z.; Zhang, Y.; Ma, X.; Wu, L.; Zhang, H.; Guo, F. Biosynthesis of selenium nanoparticles and their protective, antioxidative effects in streptozotocin induced diabetic rats. Sci. Technol. Adv. Mater. 2020, 21, 505-514. [CrossRef]

239. Mulla, N.A.; Otari, S.V.; Bohara, R.A.; Yadav, H.M.; Pawar, S.H. Rapid and size-controlled biosynthesis of cytocompatible selenium nanoparticles by Azadirachta indica leaves extract for antibacterial activity. Mater. Lett. 2020, 264, 127353. [CrossRef]

240. Alagesan, V.; Venugopal, S. Green Synthesis of Selenium Nanoparticle Using Leaves Extract of Withania somnifera and Its Biological Applications and Photocatalytic Activities. BioNanoScience 2019, 9, 105-116. [CrossRef]

241. Anu, K.; Singaravelu, G.; Murugan, K.; Benelli, G. Green-Synthesis of Selenium Nanoparticles Using Garlic Cloves (Allium sativum): Biophysical Characterization and Cytotoxicity on Vero Cells. J. Clust. Sci. 2016, 28, 551-563. [CrossRef]

242. Li, S.; Shen, Y.; Xie, A.; Yu, X.; Zhang, X.; Yang, L.; Li, C. Rapid, room-temperature synthesis of amorphous selenium/protein composites using Capsicum annuum L extract. Nanotechnology 2007, 18, 405101. [CrossRef]

243. Ramamurthy, C.; Sampath, K.S.; Arunkumar, P.; Kumar, M.S.; Sujatha, V.; Premkumar, K.; Thirunavukkarasu, C. Green synthesis and characterization of selenium nanoparticles and its augmented cytotoxicity with doxorubicin on cancer cells. Bioprocess. Biosyst. Eng. 2013, 36, 1131-1139. [CrossRef]

244. Vennila, K.; Chitra, L.; Balagurunathan, R.; Palvannan, T. Comparison of biological activities of selenium and silver nanoparticles attached with bioactive phytoconstituents: Green synthesized using Spermacoce hispida extract. Adv. Nat. Sci. Nanosci. Nanotechnol. 2018, 9, 015005. [CrossRef]

245. Kokila, K.; Elavarasan, N.; Sujatha, V. Diospyros montana leaf extract-mediated synthesis of selenium nanoparticles and their biological applications. New J. Chem. 2017, 41, 7481-7490. [CrossRef]

246. Rajaee Behbahani, S.; Iranbakhsh, A.; Ebadi, M.; Majd, A.; Ardebili, Z.O. Red elemental selenium nanoparticles mediated substantial variations in growth, tissue differentiation, metabolism, gene transcription, epigenetic cytosine DNA methylation, and callogenesis in bittermelon (Momordica charantia); an in vitro experiment. PLoS ONE 2020, 15, e0235556. [CrossRef]

247. Cui, D.; Liang, T.; Sun, L.; Meng, L.; Yang, C.; Wang, L.; Liang, T.; Li, Q. Green synthesis of selenium nanoparticles with extract of hawthorn fruit induced HepG2 cells apoptosis. Pharm. Biol. 2018, 56, 528-534. [CrossRef]

248. Fardsadegh, B.; Vaghari, H.; Mohammad-Jafari, R.; Najian, Y.; Jafarizadeh-Malmiri, H. Biosynthesis, characterization and antimicrobial activities assessment of fabricated selenium nanoparticles using Pelargonium zonale leaf extract. Green Process. Synth. 2019, 8, 191-198. [CrossRef]

249. Fardsadegh, B.; Jafarizadeh-Malmiri, H. Aloe vera leaf extract mediated green synthesis of selenium nanoparticles and assessment of their in vitro antimicrobial activity against spoilage fungi and pathogenic bacteria strains. Green Process. Synth. 2019, 8, 399-409. [CrossRef]

250. Hassanien, R.; Abed-Elmageed, A.A.I.; Husein, D.Z. Eco-Friendly Approach to Synthesize Selenium Nanoparticles: Photocatalytic Degradation of Sunset Yellow Azo Dye and Anticancer Activity. Chem. Select 2019, 4, 9018-9026. [CrossRef]

251. Mellinas, C.; Jimenez, A.; Garrigos, M.D.C. Microwave-Assisted Green Synthesis and Antioxidant Activity of Selenium Nanoparticles Using Theobroma Cacao L. Bean Shell Extract. Molecules 2019, 24, 4048. [CrossRef]

252. Menon, S.; Devi, K.S.S.; Agarwal, H.; Shanmugam, V.K. Efficacy of Biogenic Selenium Nanoparticles from an Extract of Ginger towards Evaluation on Anti-Microbial and Anti-Oxidant Activities. Colloid Interface Sci. Commun. 2019, 29, 1-8. [CrossRef]

253. Wang, L.; Li, C.; Huang, Q.; Fu, X. Biofunctionalization of selenium nanoparticles with a polysaccharide from Rosa roxburghii fruit and their protective effect against $\mathrm{H}_{2} \mathrm{O}_{2}$-induced apoptosis in INS-1 cells. Food Funct. 2019, 10, 539-553. [CrossRef]

254. Zhang, W.; Zhang, J.; Ding, D.; Zhang, L.; Muehlmann, L.A.; Deng, S.E.; Wang, X.; Li, W.; Zhang, W. Synthesis and antioxidant properties of Lycium barbarum polysaccharides capped selenium nanoparticles using tea extract. Artif. Cell Nanomed. Biotechnol. 2017, 46, 1463-1470. [CrossRef]

255. Ezhuthupurakkal, P.B.; Polaki, L.R.; Suyavaran, A.; Subastri, A.; Sujatha, V.; Thirunavukkarasu, C. Selenium nanoparticles synthesized in aqueous extract of Allium sativum perturbs the structural integrity of Calf thymus DNA through intercalation and groove binding. Mater. Sci. Eng. C Mater. Biol. Appl. 2017, 74, 597-608. [CrossRef] 
256. Tanaka, Y.K.; Takada, S.; Kumagai, K.; Kobayashi, K.; Hokura, A.; Ogra, Y. Elucidation of tellurium biogenic nanoparticles in garlic, Allium sativum, by inductively coupled plasma-mass spectrometry. J. Trace Elem. Med. Biol. 2020, 62, 126628. [CrossRef]

257. Anan, Y.; Yoshida, M.; Hasegawa, S.; Katai, R.; Tokumoto, M.; Ouerdane, L.; Lobinski, R.; Ogra, Y. Speciation and identification of tellurium-containing metabolites in garlic, Allium sativum. Metallomics 2013, 5, 1215-1224. [CrossRef]

258. Cowgill, U.M. The Tellurium Content of Vegetation. Biol. Trace Elem. Res. 1988, 17, 43-67. [CrossRef]

259. Yurkov, V.; Jappé, J.; Verméglio, A. Tellurite Resistance and Reduction by Obligately Aerobic Photosynthetic Bacteria. Appl. Environ. Microbiol. 1996, 62, 4195-4198. [CrossRef]

260. Sridharan, K.; Ollakkan, M.S.; Philip, R.; Park, T.J. Non-hydrothermal synthesis and optical limiting properties of one-dimensional $\mathrm{Se} / \mathrm{C}, \mathrm{Te} / \mathrm{C}$ and Se-Te/C core-shell nanostructures. Carbon 2013, 63, 263-273. [CrossRef]

261. Fu, S.; Cai, K.; Wu, L.; Han, H. One-step synthesis of high-quality homogenous Te/Se alloy nanorods with various morphologies. CrystEngComm 2015, 17, 3243-3250. [CrossRef]

262. Baesman, S.M.; Stolz, J.F.; Kulp, T.R.; Oremland, R.S. Enrichment and isolation of Bacillus beveridgei sp. nov., a facultative anaerobic haloalkaliphile from Mono Lake, California, that respires oxyanions of tellurium, selenium, and arsenic. Extremophiles 2009, 13, 695-705. [CrossRef]

263. Bajaj, M.; Winter, J. Se (IV) triggers faster Te (IV) reduction by soil isolates of heterotrophic aerobic bacteria: Formation of extracellular SeTe nanospheres. Microb. Cell Fact. 2014, 13, 168. [CrossRef]

264. Thanh, N.T.K.; Green, L.A.W. Functionalisation of nanoparticles for biomedical applications. Nano Today 2010, 5, 213-230. [CrossRef]

265. Salata, O.V. Applications of nanoparticles in biology and medicine. J. Nanobiotechnol. 2004, 2, 3. [CrossRef]

266. Zamora-Ledezma, C.; Clavijo, C.D.F.; Medina, E.; Sinche, F.; Santiago Vispo, N.; Dahoumane, S.A.; Alexis, F. Biomedical Science to Tackle the COVID-19 Pandemic: Current Status and Future Perspectives. Molecules 2020, 25, 4620. [CrossRef]

267. Mout, R.; Moyano, D.F.; Rana, S.; Rotello, V.M. Surface functionalization of nanoparticles for nanomedicine. Chem. Soc. Rev. 2012, 41, 2539-2544. [CrossRef]

268. Soloviev, M. Nanobiotechnology today: Focus on nanoparticles. J. Nanobiotechnol. 2007, 5, 11. [CrossRef]

269. Zhang, J.; Wang, X.; Xu, T. Elemental selenium at nano size (Nano-Se) as a potential chemopreventive agent with reduced risk of selenium toxicity: Comparison with se-methylselenocysteine in mice. Toxicol. Sci. 2008, 101, 22-31. [CrossRef]

270. Wang, H.; Zhang, J.; Yu, H. Elemental selenium at nano size possesses lower toxicity without compromising the fundamental effect on selenoenzymes: Comparison with selenomethionine in mice. Free Radic. Biol. Med. 2007, 42, 1524-1533. [CrossRef]

271. Kheradmand, E.; Rafii, F.; Yazdi, M.H.; Sepahi, A.A.; Shahverdi, A.R.; Oveisi, M.R. The antimicrobial effects of selenium nanoparticleenriched probiotics and their fermented broth against Candida albicans. DARU J. Pharm. Sci. 2014, 22, 48. [CrossRef] [PubMed]

272. Shakibaie, M.; Adeli-Sardou, M.; Mohammadi-Khorsand, T.; ZeydabadiNejad, M.; Amirafzali, E.; Amirpour-Rostami, S.; Ameri, A.; Forootanfar, H. Antimicrobial and Antioxidant Activity of the Biologically Synthesized Tellurium Nanorods; A Preliminary In vitro Study. Iran. J. Biotechnol. 2017, 15, 268-276. [CrossRef] [PubMed]

273. Chang, C.; Gershwin, M.E. Drugs and autoimmunity -a contemporary review and mechanistic approach. J. Autoimmun. 2010, 34, J266-J275. [CrossRef] [PubMed]

274. Inoue, K.; Takano, H.; Yanagisawa, R.; Ichinose, T.; Sakurai, M.; Yoshikawa, T. Effects of nano particles on cytokine expression in murine lung in the absence or presence of allergen. Arch. Toxicol. 2006, 80, 614-619. [CrossRef]

275. Liao, C.; Li, Y.; Tjong, S.C. Bactericidal and Cytotoxic Properties of Silver Nanoparticles. Int. J. Mol. Sci. 2019, 20. [CrossRef]

276. Ahmad, M.S.; Yasser, M.M.; Sholkamy, E.N.; Ali, A.M.; Mehanni, M.M. Anticancer activity of biostabilized selenium nanorods synthesized by Streptomyces bikiniensis strain Ess_amA-1. Int. J. Nanomed. 2015, 10, 3389-3401. [CrossRef]

277. Filipe, V.; Hawe, A.; Jiskoot, W. Critical evaluation of Nanoparticle Tracking Analysis (NTA) by NanoSight for the measurement of nanoparticles and protein aggregates. Pharm. Res. 2010, 27, 796-810. [CrossRef]

278. Prasad, K.S.; Vyas, P.; Prajapati, V.; Patel, P.; Selvaraj, K. Biomimetic synthesis of selenium nanoparticles using cell-free extract of Microbacterium sp. ARB05. Micro. Nano Lett. 2012, 7, 1-4. [CrossRef]

279. Selenius, M.; Rundlo, A.-K.; Olm, E.; Fernandes, A.P.; Björnstedt, M. Selenium and the Selenoprotein Thioredoxin Reductase in the Prevention, Treatment and Diagnostics of Cancer. Antioxid. Redox Sign. 2010, 12, 867-880. [CrossRef]

280. Bao, P.; Xiao, K.Q.; Wang, H.J.; Xu, H.; Xu, P.P.; Jia, Y.; Haggblom, M.M.; Zhu, Y.G. Characterization and Potential Applications of a Selenium Nanoparticle Producing and Nitrate Reducing Bacterium Bacillus oryziterrae sp. nov. Sci. Rep. 2016, 6, 34054. [CrossRef]

281. Schrauzer, G.N. Anticarcinogenic effects of selenium. CMLS Cell Mol. Life Sci. 2000, 57, 1864-1873. [CrossRef]

282. Zeng, H.; Combs, G.F., Jr. Selenium as an anticancer nutrient: Roles in cell proliferation and tumor cell invasion. J. Nutr. Biochem. 2008, 19, 1-7. [CrossRef] [PubMed]

283. Brown, C.D.; Cruz, D.M.; Roy, A.K.; Webster, T.J. Synthesis and characterization of PVP-coated tellurium nanorods and their antibacterial and anticancer properties. J. Nanopart. Res. 2018, 20, 254. [CrossRef]

284. Mohanty, A.; Kathawala, M.H.; Zhang, J.; Chen, W.N.; Chye Loo, J.S.; Kjelleberg, S.; Yang, L.; Cao, B. Biogenic Tellurium Nanorods as a Novel Antivirulence Agent Inhibiting Pyoverdine Production in Pseudomonas aeruginosa. Biotechnol. Bioeng. 2013, 111, 858-865. [CrossRef] [PubMed]

285. Aydin, N.; Arslan, M.E.; Sonmez Sonmez, E.; Turkez, H. Cytotoxicity analysis of tellurium dioxide nanoparticles on cultured human pulmonary alveolar epithelial and peripheral blood cell cultures. Biomed. Res. India 2017, 28, 3300-3304. 
286. Forootanfar, H.; Amirpour-Rostami, S.; Jafari, M.; Forootanfar, A.; Yousefizadeh, Z.; Shakibaie, M. Microbial-assisted synthesis and evaluation the cytotoxic effect of tellurium nanorods. Mater. Sci. Eng. C Mater. Biol. Appl. 2015, 49, 183-189. [CrossRef] [PubMed]

287. Wen, H.; Zhong, J.; Shen, B.; Gan, T.; Fu, C.; Zhu, Z.; Li, R.; Yang, X. Comparative study of the cytotoxicity of the nanosized and microsized tellurium powders on HeLa cells. Front. Biol. 2013, 8, 444-450. [CrossRef] 